\title{
Seasonal Variation, Export Dynamics and Consumption of Freshwater Invertebrates in an Estuarine Environment
}

\author{
D. D. Williams $s^{a, c}$ and N. E. Williams ${ }^{b, c}$
}

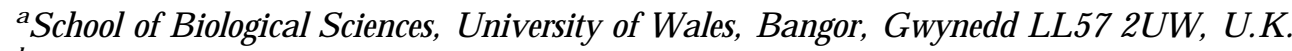

b Institute of Earth Studies, U niversity of W ales, A berystwyth, Dyfed SW 23 3D B, U.K.

Received 7 F ebruary 1997 and accepted in revised form 31 J uly 1997

\begin{abstract}
In the Aber Estuary, North Wales, significant numbers of freshwater benthic invertebrates occurred in the tidal freshwater area. Distinct seasonal patterns were observed in their longitudinal zonation which appeared to be unrelated to variations in tidal inundation. The December extension downstream of freshwater taxa is hypothesized to be in response to decreasing water temperatures. In April, larvae/nymphs of the Trichoptera (caddisflies), Ephemeroptera (mayflies) and Plecoptera (stoneflies) ranged as far as a site inundated by $80.9 \%$ of all high tides, and larval Elmidae and Chironomidae (midges) occurred at the most marine site (inundated twice daily by all high tides). In July, with the exception of the Chironomidae, the range of most aquatic insects had contracted to the upper estuary. Although, in general, densities of aquatic insects decreased towards the lower estuary, significant densities persisted there. For example, maxima of 3514 chironomid larvae and 48 caddisfly larvae $\mathrm{m}^{-2}$ were recorded at the $80.9 \%$ inundation site. An estimated $31 \times 10^{6}$ freshwater invertebrates (weighing $62.6 \mathrm{~kg}$ ), per annum, passed from fresh water into salt water across any given transect along the estuary. In comparison, the annual influx of invertebrates carried upstream by incoming tides was estimated to be $1.9 \times 10^{6}(6.2 \%$; weighing $2.5 \mathrm{~kg})$. Predominant in the downstream drift were the larvae/nymphs and/or pupae of chironomids, mayflies, stoneflies and caddisflies. The ' reverse' drift comprised mainly copepods, ostracods, amphipods and oligochaetes. Mites and the brackishwater amphipod Gammarus zaddachi commonly moved in both directions. Highest drift densities occurred in July, whereas the lowest densities occurred in late autumn and winter. Multiple regression analysis showed no relationship between total drift or 'reverse' drift densities and any of the measured environmental variables. Many of the freshwater invertebrates appeared not to die upon passing into tidal sections but resumed a benthic existence by virtue of varying degrees of salt tolerance. Of the three fish species common in the estuary, eel, common goby and flounder, the last two preyed measurably on freshwater taxa. Whereas gobies tended to be opportunistic feeders, depending on the section of estuary that they occupied, flounder were more restricted to the upper estuary where they fed selectively on chironomid larvae. On the latter diet, between March and September, the mean wet weight of flounders increased by more than 100 times (from 5 to $540 \mathrm{mg}$ ). Gobies were more numerous in the estuary from September to February, and although they ate insects their primary prey was G. zaddachi.
\end{abstract}

(C) 1998 Academic Press Limited

Keywords: tidal fresh water; freshwater invertebrates; lotic insects; longitudinal zonation; seasonal changes; drift; Platichthys; Pomatoschistus; estuarine fish diets; fish growth; Wales

\section{Introduction}

As rivers approach coastlines, they become influenced by salt water which periodically inundates freshwater communities and processes (tidal freshwater area, sensu Schuchardt et al., 1993). There are varying degrees of inundation which are used, conceptually, to classify the different types of transitional environments, or estuaries. Typically this variation is predictable both in time and space. Along any estuary, there is a gradient in salinity which results in a longitudinal zonation of the biota. The classic pattern is one of cAddress for correspondence: Division of Life Sciences, University of Toronto at Scarborough, 1265 Military Trail, Scarborough, Ontario, Canada M1C 1A4. dominance of marine-derived taxa at the seaward end, occurrence of largely freshwater taxa at the landward end, and of a specialized, although somewhat depauperate, group of brackishwater-adapted taxa in between (e.g. Remane \& Schlieper, 1971; Perkins, 1974; Cunha \& Moreira, 1995). Whereas, there has been considerable study of the lower ends of estuaries together with their mesohaline faunas (e.g. Boesch et al., 1976; Day et al., 1989), in general, the freshwater invertebrate components of estuarine communities (termed 'tidal freshwater fauna' by some, e.g. Diaz, 1994) have been given short shrift by oceanographers and lotic biologists alike (Odum et al., 1984; Laffoley \& Hiscock, 1993; Schuchardt et al., 1993). 
Further, the contribution of freshwater invertebrates (as downstream 'drift') to estuarine consumers is poorly known (Williams, 1980). Of concern is the fact that due to sewage and industrial discharges into the upper sections of estuaries, the diversity of this freshwater component is being replaced by a predominance of pollution-tolerant oligochaetes (McLusky et al., 1993).

The present study aimed to provide information on the tidal freshwater fauna through a detailed, year round, qualitative and quantitative study of a riverdominated estuary in North Wales. The specific aims were: (1) to provide a description of the seasonal variation in the longitudinal distributions of the freshwater invertebrates; (2) to gather qualitative and quantitative data on the drift of these invertebrates across the freshwater seawater interface; and (3) to examine the gut contents of the predominant fishes in the estuary to determine if they feed on any of the freshwater taxa.

\section{Study site}

The Afon Aber, located in the county of Gwynedd, North Wales $\left(54^{\circ} 14^{\prime} \mathrm{N}, 4^{\circ} 00^{\prime} \mathrm{W}\right)$, arises in the Carneddau mountain range. Its catchment is $24.5 \mathrm{~km}^{2}$ and the watercourse itself comprises 82 first-order streams, 13 second-order streams, three third-order streams, and one fourth-order stream. The upper Aber Valley is composed of boulder clay, whereas the valley floor is made up largely of fluvio-glacial sand and gravel. Alluvium is present near the estuary mouth (Brown, 1960; Bassett, 1967). The upper watershed supports rough grazing for sheep, followed successively downstream by areas of coniferous plantation, the village of Aber, flat pasture and, finally, salt marsh.

Observation of water mass movements together with salinity measurements over 12 months, show the Aber Estuary to be of the freshwater-dominated, stratified, type. Freshwater flow-rates vary annually between about 30 and $110 \mathrm{~cm} \mathrm{~s}^{-1}$ (discharge range $=0.27$ to 1.98 cumecs). The estuary is stratified on both rising and ebb tides, with a denser, bottom salt wedge that envelops the benthos. At the extreme edge of the wedge front (typically around $5-10 \mathrm{~cm}$ thick), salinity ranged between 8 and 17 . Tides along this part of the Gwynedd shoreline are semi-diurnal with maximum annual tidal range of about $8 \mathrm{~m}$ on the open coast. Organisms on the estuary bed are thus subject to saltwater inundation twice daily.

Five sampling stations, each characterized by a different degree of saltwater inundation, were set up along the estuary (Figure 1). They were:

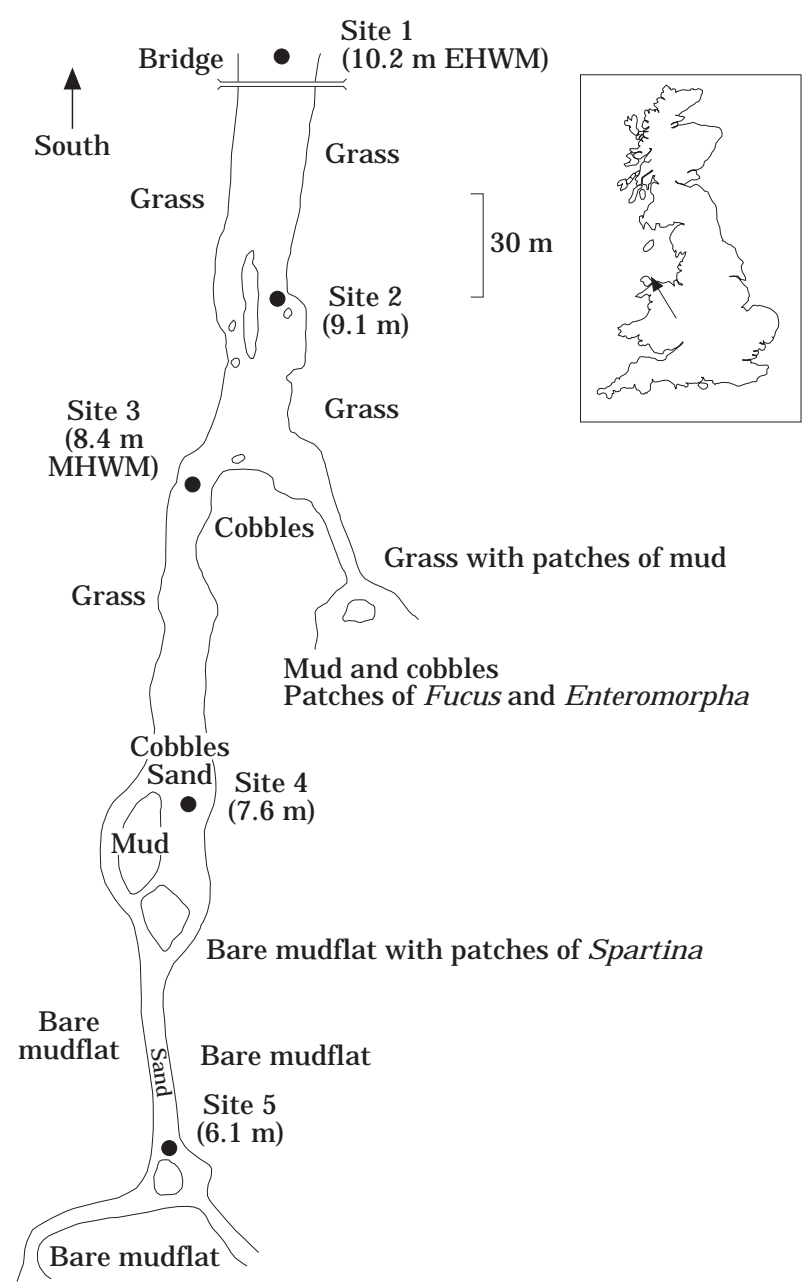

FIgURE 1. Map of the Aber Estuary showing features of the bed and channel, together with the five sampling sites located at specific tide heights (note that Site 1 is above the Extreme High Water Mark). Direction of the river flow is from top to bottom.

(1) At a point $5 \mathrm{~m}$ upstream of the maximum intrusion of the highest spring tide (extreme high water mark, EHWM $=10 \cdot 2 \mathrm{~m}$ ); here the benthic fauna was exposed only to fresh water.

(2) At the $9.1 \mathrm{~m}$ mark; here the benthos was inundated by $33.7 \%$ of all high tides.

(3) At the $8.4 \mathrm{~m}$ mark which, in this region, represented the level of the mean high water mark (MHWM); here benthos was inundated by $50 \%$ of all high tides.

(4) At the $7.6 \mathrm{~m}$ mark; inundation by $80.9 \%$ of all high tides.

(5) At the $6 \cdot 1 \mathrm{~m}$ mark; inundation by $100 \%$ of all high tides.

Percent of inundation by high tides was calculated by graphing the daily low and high tide heights at Menai Bridge over the previous year (1989-90), and 
choosing a range of values for which corresponding sites along the Aber Estuary could be found. Sites were located at the appropriate times of high tide, and marker stakes were driven into the bed. Subsequent inundation measurements made during the study year (1990-91) showed some seasonal variation around the designated sites. For example, taking Site 3 (designated $50 \%$ inundation) as a reference point, $65 \%$ of all high tides inundated this site in April, compared with only $45 \%$ in June, $55 \%$ in September, and $50 \%$ in December.

At Sites $1-3$, the substratum was typically riverine, comprising cobbles (up to $30 \mathrm{~cm}$ in diameter), stones, coarse and fine gravels, and coarse sand. At Site 4, there was much more sand, and at Site 5, the substratum was almost entirely sand. Whereas, there was evidence of occasional water-induced bed disturbance at these latter two sites, the substratum at the three uppermost sites remained largely undisturbed over the entire study period.

\section{Materials and methods}

Each site was sampled for benthic invertebrates at 3-month intervals over the period September 1990July 1991. Samples were taken to a substratum depth of $5 \mathrm{~cm}$, using a $250 \mu \mathrm{m}$ mesh Surber Sampler (Surber, 1937) with a sampling area of $900 \mathrm{~cm}^{2}$. Three, randomly positioned, replicate samples were taken from near the midline of the estuary bed at each site, starting, on each occasion, at Site 5 and working upstream. Samples were preserved in $95 \%$ ethanol in the field. In the laboratory, the samples were rinsed with tap water, floated in saturated calcium chloride solution (to help separate the animals from the inorganic substratum), and examined under a dissecting microscope. Individual animals were removed from the surrounding detritus, identified and preserved in $75 \%$ ethanol.

Drifting animals were sampled for 24 continuous hours, each month from early September to the end of July, using two nets. Each $250 \mu \mathrm{m}$ mesh nylon net was $1 \mathrm{~m}$ long, with a $24 \times 44 \mathrm{~cm}$ opening. Attached to the opening was a reversed, galvanized metal funnel which reduced the effective entry port to a narrow vertical slit measuring $5 \times 20 \mathrm{~cm}$. Reduction of the sampling window in this manner is standard practise in drift research as it prevents excess fine particulate material from entering the net, clogging up the mesh and causing a bow-wave effect at the net mouth with consequent loss of part of the sample. The two nets were attached to iron posts driven into the estuary bed and had their lower edges resting on the substratum with the funnel mouths facing upstream. The nets were located $1 \mathrm{~m}$ apart at the $8.7 \mathrm{~m}$ tide level in the estuary, a point inundated by approximately $40 \%$ of all high tides. The channel width, at low tide, at this point was for example, in September, approximately $4.5 \mathrm{~m}$, with a freshwater depth of $20 \mathrm{~cm}$ and a current speed of around $35 \mathrm{~cm} \mathrm{~s}^{-1}$. Seasonal variations in freshwater flow conditions are given in Table 1. Sampling times were chosen always to coincide with a high tide that did not reach the nets and therefore 'contaminate' them. After $24 \mathrm{~h}$, the contents were emptied into polyethylene bags and preserved with 95\% ethanol.

'Reverse' drift, that is organisms moving up the estuary on incoming tides, was sampled, again monthly, using the same nets but positioned with the funnel entrances facing downstream. The nets were attached to stakes at the $8.4 \mathrm{~m}$ tide level and remained in place for $24 \mathrm{~h}$, that is through two high tides. To prevent loss of collected materials due to flushing by fresh water during the intervening low tide, a baffle was inserted into each funnel. Additionally, the distal end of each net was tied to an upstream stake, to prevent collapse by the force of the fresh water.

In the laboratory, both drift and reverse drift samples were processed by separating the invertebrates from background detritus, the latter being visually assessed, dried and weighed (Table 1). The invertebrates were identified to species, wherever possible, counted and wet weighed.

Collections of the fishes living in the Aber Estuary were made both at low tide and at moderately high tides using both a $10 \mathrm{~m}$ seine $(1 \mathrm{~cm}$ mesh) and, more successfully, a $45 \mathrm{~cm}$ wide dipnet $(250 \mu \mathrm{m}$ mesh). Collections were made on eight separate occasions throughout the year between Sites 2 and 5 . Specimens were preserved immediately in $10 \%$ formalin solution. In the laboratory, they were identified, measured (body length and maximum mouth gape) and assigned to length size classes which were based on total size range rather than on specific cohorts. Subsequently, their stomach contents were removed for diet analysis. Three measures were calculated:

(1) The Index of Relative Importance (I.R.I.) of Pinkas et al. (1971). This was calculated as:

$$
\text { I.R.I. }=(\% \mathrm{~N}+\% \mathrm{~V}) \times \% \mathrm{FO}
$$

where $\% \mathrm{~N}$ is the numerical percentage of a food type, $\% \mathrm{~V}$ is its volumetric percentage, and $\% \mathrm{FO}$ is its percentage frequency of occurrence in the gut.

(2) The Food Niche Breadth Index (W) of Petraitis (1979). W incorporates an expression of potential prey availability and is approximately equal to the 
TABLE 1. Environmental data associated with the times at which the drift samples were taken in the Aber Estuary

\begin{tabular}{|c|c|c|c|c|c|c|c|}
\hline \multirow[b]{2}{*}{ Date } & \multirow{2}{*}{$\begin{array}{l}\text { Water } \\
\text { depth } \\
(\mathrm{cm})\end{array}$} & \multirow{2}{*}{$\begin{array}{l}\text { Current } \\
\left(\mathrm{cm} \mathrm{s}^{-1}\right)\end{array}$} & \multirow{2}{*}{$\begin{array}{c}\text { River } \\
\text { temperature } \\
\left({ }^{\circ} \mathrm{C}\right)\end{array}$} & \multirow{2}{*}{$\begin{array}{c}\text { Organic } \\
\text { matter } \\
\text { (g dry wt) }\end{array}$} & \multicolumn{2}{|c|}{ Total number of invertebrates } & \multirow[t]{2}{*}{$\begin{array}{l}\text { Biomass } \\
\text { (g) }\end{array}$} \\
\hline & & & & & Counts & Density $^{a}$ & \\
\hline September & 20 & 35 & $13 \cdot 0$ & $\begin{array}{c}5 \cdot 9 \\
\text { Green leaves }\end{array}$ & 581 & 1816 & $888 \cdot 3$ \\
\hline October & 30 & 50 & $12 \cdot 5$ & $\begin{array}{l}56 \cdot 2 \\
\text { Green leaves }\end{array}$ & 340 & 500 & $4302 \cdot 2$ \\
\hline November & 30 & 55 & $7 \cdot 0$ & $\begin{array}{c}80 \cdot 6 \\
\text { Green leaves }\end{array}$ & 127 & 172 & $1454 \cdot 0$ \\
\hline December & 37 & 90 & $4 \cdot 0$ & $\begin{array}{l}33 \cdot 5 \\
\text { Brown leaves }\end{array}$ & 620 & 413 & $5932 \cdot 8$ \\
\hline January & 32 & 65 & $2 \cdot 0$ & $\begin{array}{l}51 \cdot 4 \\
\text { Brown leaves }\end{array}$ & 203 & 216 & $506 \cdot 7$ \\
\hline February & 22 & 45 & $4 \cdot 5$ & $\begin{array}{c}53 \cdot 2 \\
\text { Brown leaves }\end{array}$ & 540 & 1200 & $9244 \cdot 6$ \\
\hline March & 28 & 50 & $5 \cdot 0$ & $\begin{array}{c}13 \cdot 2 \\
\text { Leaves }+ \text { CPOM }\end{array}$ & 942 & 150 & $3665 \cdot 8$ \\
\hline May & 40 & 85 & $6 \cdot 0$ & $\begin{array}{c}16 \cdot 2 \\
\text { Leaves + CPOM }\end{array}$ & 3234 & 2114 & $18740 \cdot 4$ \\
\hline June & 40 & 85 & $9 \cdot 0$ & $\begin{array}{l}\qquad 14 \cdot 7 \\
\text { Filamentous algae/green leaves }\end{array}$ & 825 & 539 & $2346 \cdot 3$ \\
\hline July & 30 & 50 & $16 \cdot 0$ & $\begin{array}{c}3 \cdot 8 \\
\text { Filamentous algae/green leaves }\end{array}$ & 2409 & 3542 & $2787 \cdot 2$ \\
\hline
\end{tabular}

${ }^{\mathrm{a}}$ Drift densities were calculated from the drift counts converted to standard river discharge and represent number $\mathrm{m}^{-3} 24 \mathrm{~h}^{-1}$.

chi-square goodness-of-fit test. $W$ ranges from a value of 0 (specialist feeder) to $1 \cdot 0$ (generalist feeder) and measures the likelihood that the observed proportional resource usages are the same as the proportions available. It was calculated as:

$$
\begin{gathered}
W=(\partial)^{1 / N} \\
\ln \partial=\sin _{i} \ln \left(a_{i}\right)-\sin _{i} \ln \left(P x_{i}\right)
\end{gathered}
$$

where $P x_{i}$ is the proportion of food type $i$ in species $x$; $n_{i}$ is the amount of resource $i$ used; $a_{i}$ is the number of food type $i$ in the environment; and $N$ is the total number of resources used.

(3) The Niche Overlap Index $\left(C_{x y}\right)$ of Schoener (1970). Values of $C_{x y}$ range from 0 (no overlap) to 1 (complete overlap), with values $>0 \cdot 6$ considered to be biologically significant. It was calculated as:

$$
C_{x y}=1-0 \cdot 5\left(\Sigma\left[P x_{i}-P y_{i}\right]\right)
$$

where $P x_{i}$ is the numerical proportion of food type $i$ in the diet of species $\mathrm{X}$ and $\mathrm{Py}_{\mathrm{i}}$ is the numerical proportion of food type $\mathrm{i}$ in the diet of species $\mathrm{y}$. See Delbeek and Williams (1987) for further details of these protocols. Prior to statistical analyses, the data were examined for normality and homoscedasticity, and were transformed to $\log x$ where appropriate.

\section{Results}

L ongitudinal zonation of the fauna and its seasonal variation

The distribution patterns of the major taxa found at the five sampling sites along the Aber Estuary can be assigned to three basic categories, illustrated by the September dataset (Figure 2). The first pattern was of a largely upstream distribution (Site 1) and was seen best in the caddisflies and mayflies. Chironomid and simuliid larvae were found as far downstream as Site 4. A few live elmid beetle larvae and stonefly nymphs were found at Site 5 . The second pattern was of a largely downstream distribution and was seen in the marine-derived taxa, for example the bivalves, gastropods, polychaetes, ostracods and decapods. With the exception of some ostracods (where there were both freshwater and marine species present), none of the marine taxa was found further upstream than Site 3. The third distribution pattern was intermediate and exhibited by brackishwater taxa, for example the amphipods and isopods. Their numbers were typically greatest at Sites 2, 3 and 4. The distributions of a few taxa did not fit the above three patterns, as they were complicated by a succession of species that spread the range of their group over the five sites, for example the oligochaetes, nematodes and mites. Chironomid 
Freshwater invertebrate variations in an estuarine environment 397

SEPTEMBER

APRIL

JULY
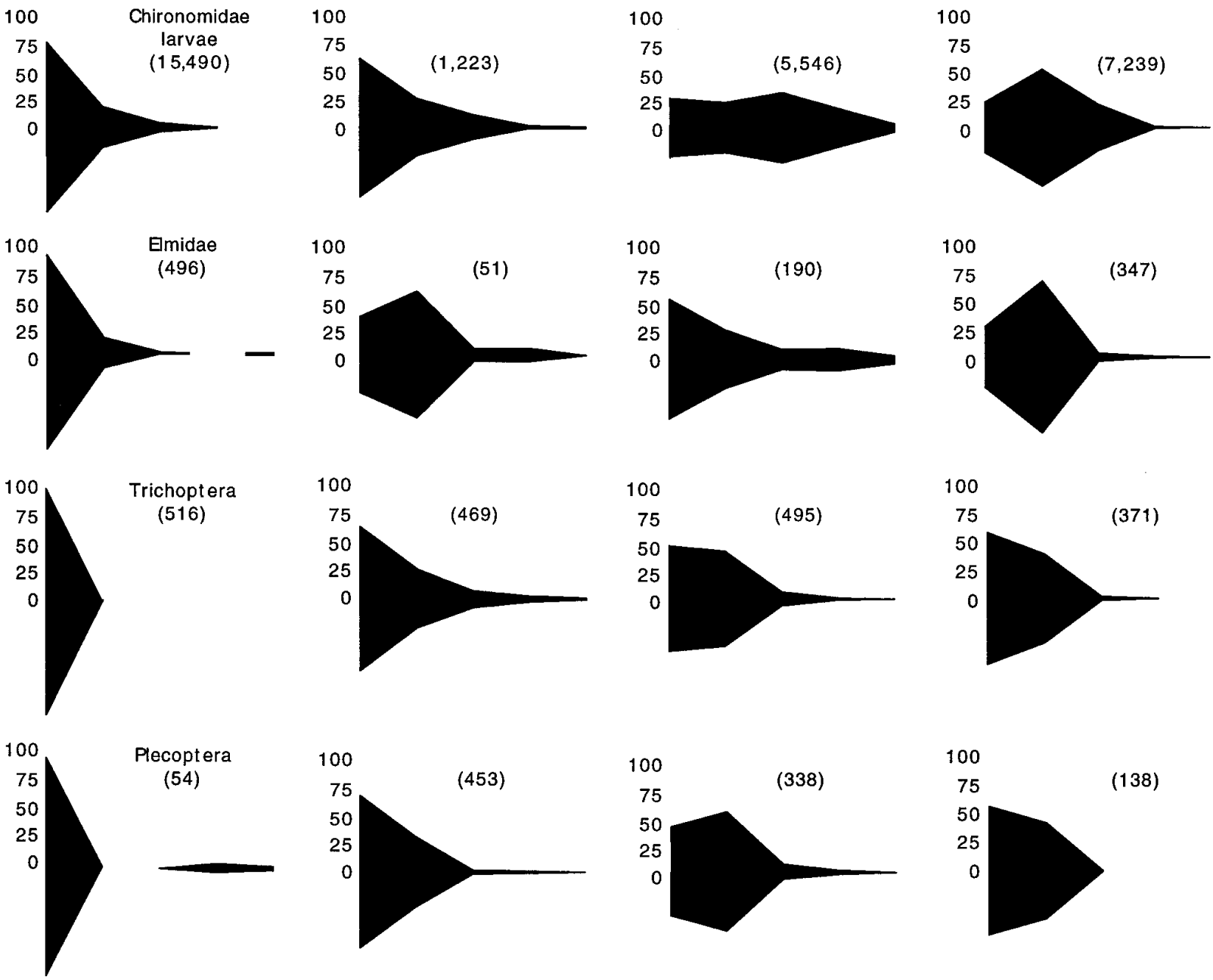

(138)
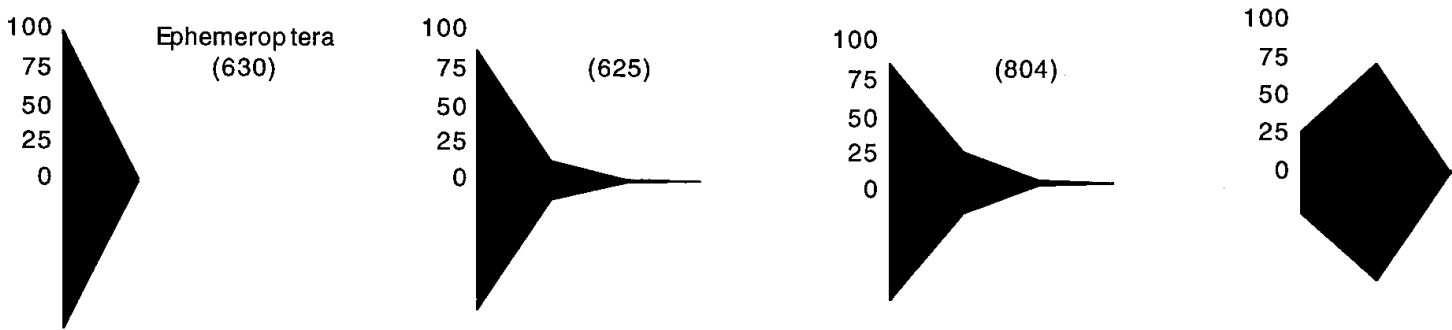

$(2,377)$

(630)
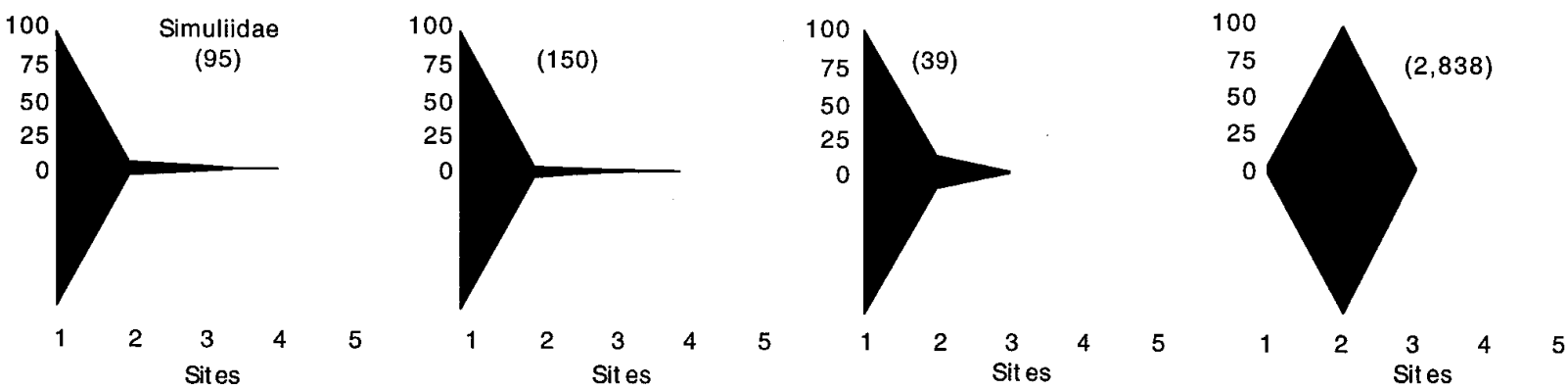

FIGURE 2. Longitudinal zonation of the major invertebrate taxa across the five sites (Site 1 being the most landward site). The kite diagrams represent percent occurrence based on the total numbers of animals found on each sampling occasion (indicated in brackets). Taxa are arranged beginning with those largely occurring in the upper estuary and ending with those occurring predominantly in the lower estuary. 
398 D. D. Williams \& N. E. Williams

SEPTEMBER
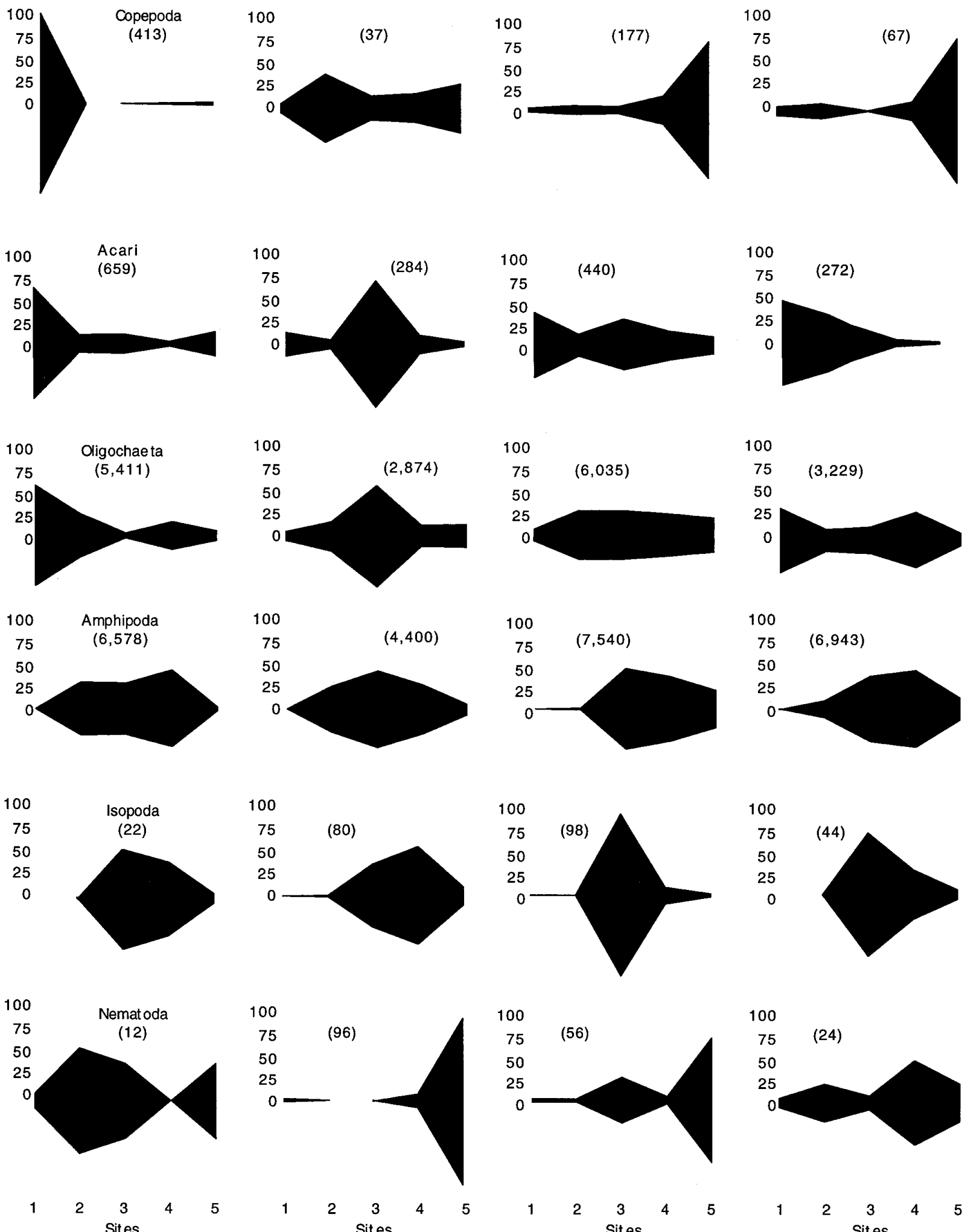

DECBMBA
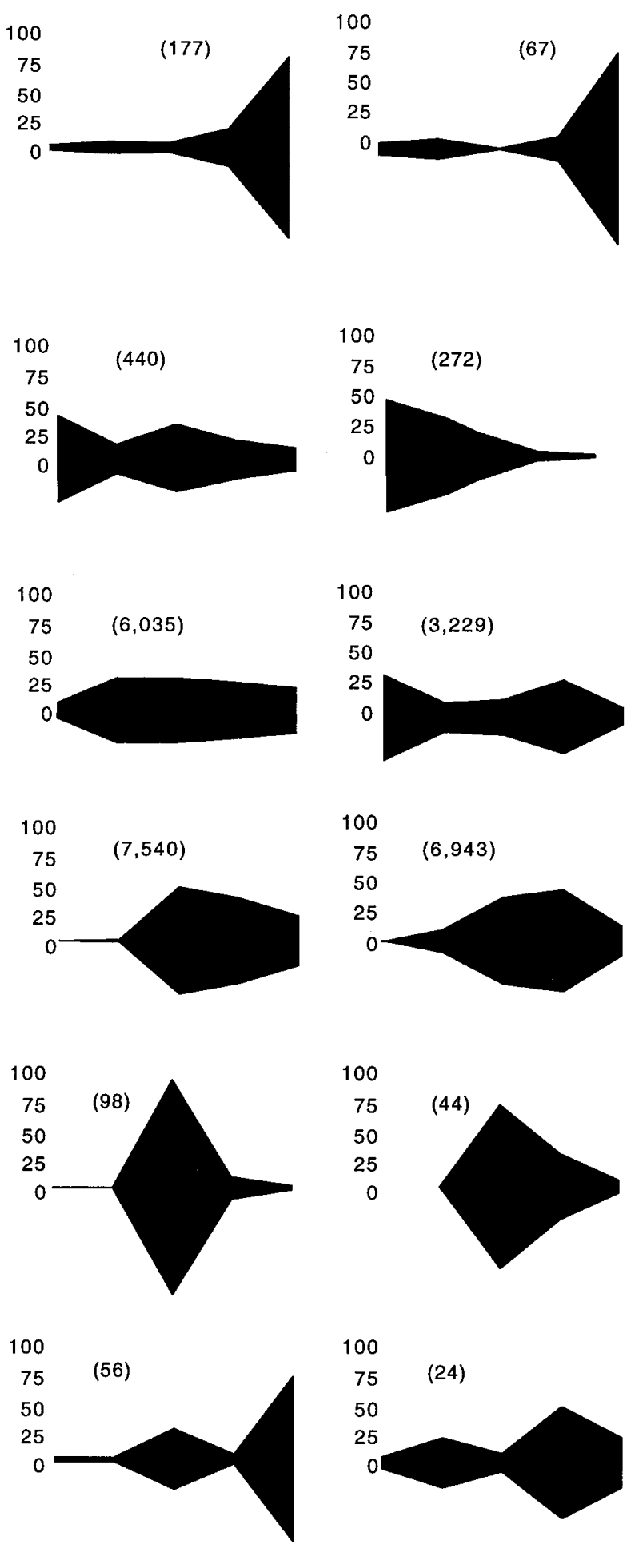

100

75

50
25

24)

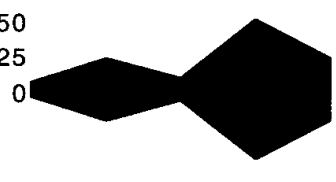

$\begin{array}{cccccc}3 & 4 & 5 & 1 & 2 & 3 \\ \text { Sites } & & & & & \end{array}$

FIGURE 2. (continued) 
Freshwater invertebrate variations in an estuarine environment 399
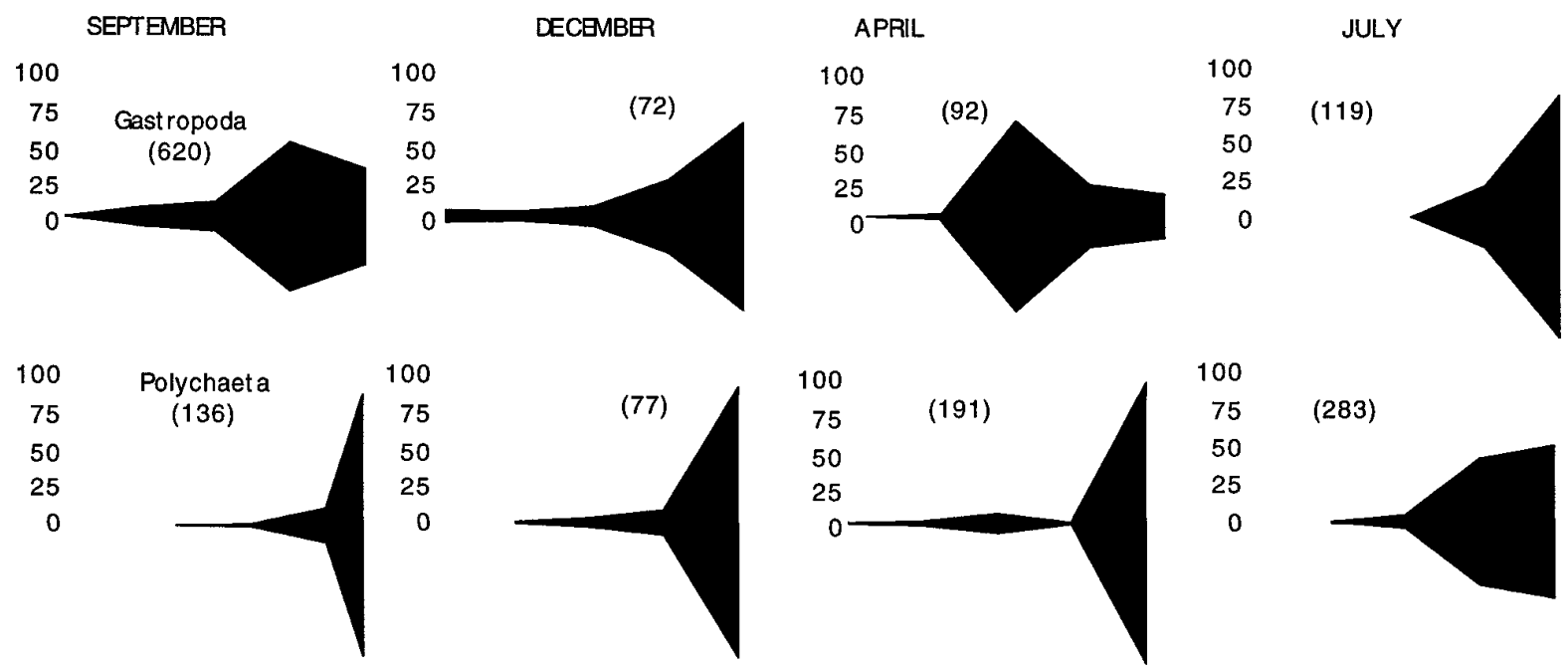

(283)
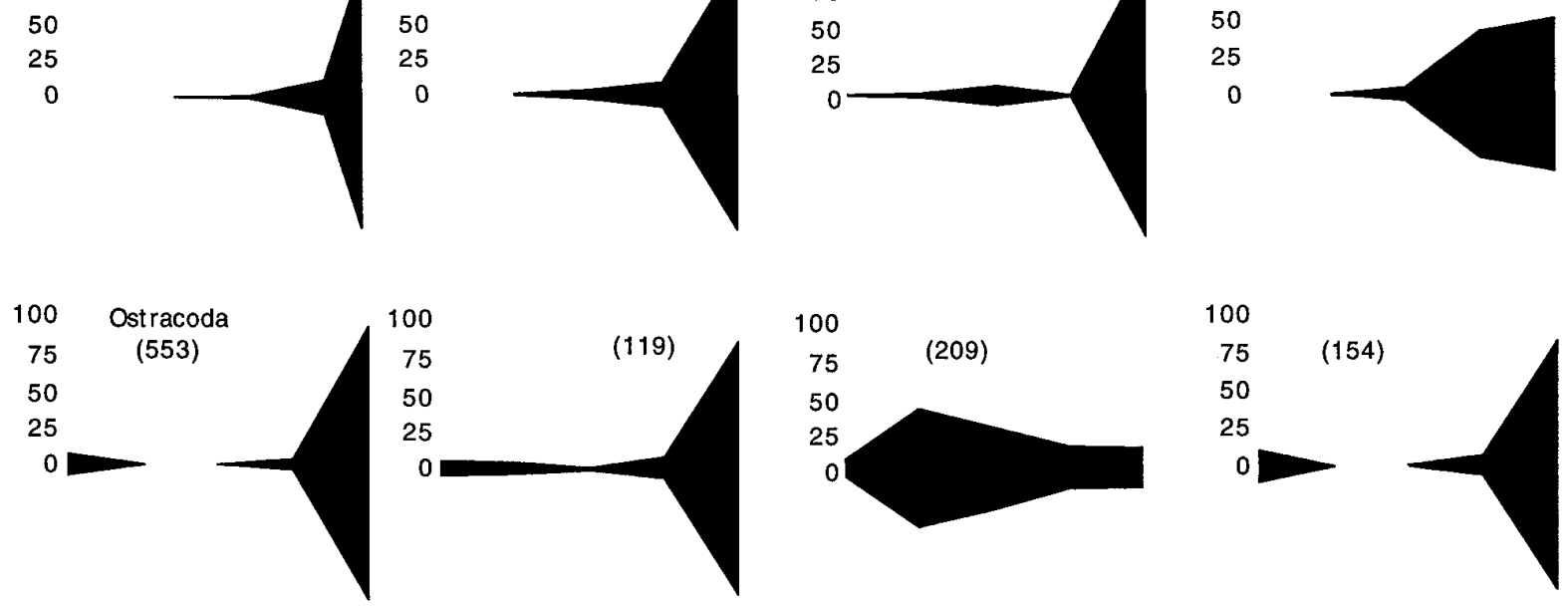

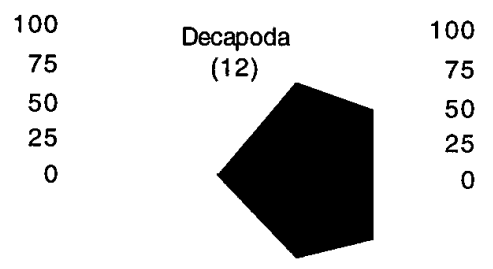

(13)
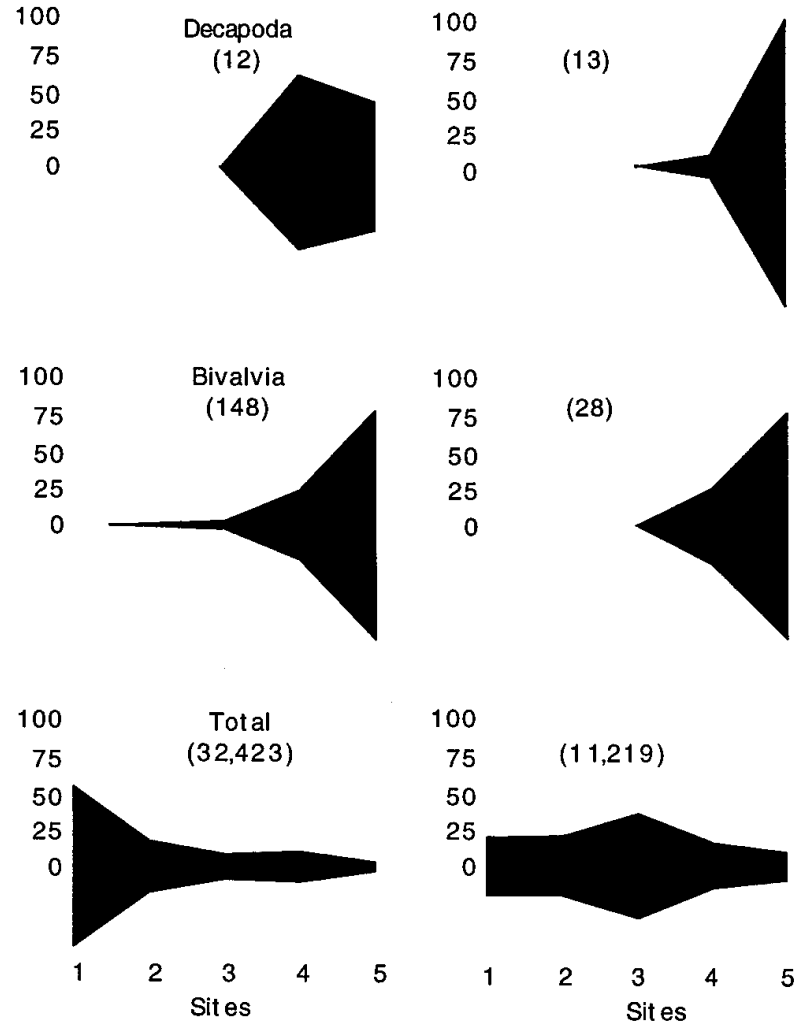

(28)
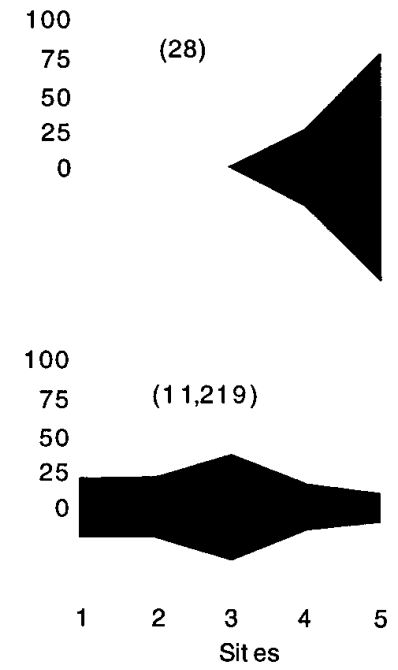
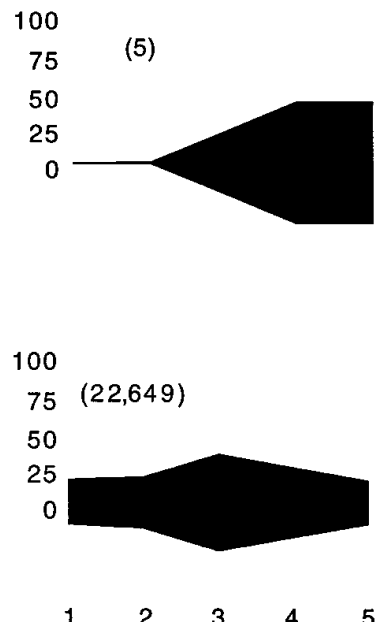

100
75
50
25
0

(8)
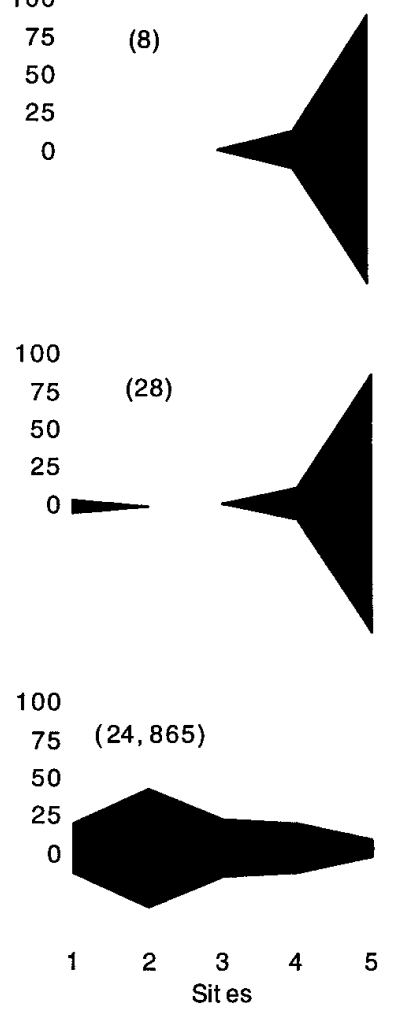

FIgURE 2. (Continued) 
pupae and adults were caught at Sites 2 and 3 in greater proportions than the larvae, and this probably reflects their increased vulnerability to being displaced by the current during these life cycle stages. In terms of the overall distribution of invertebrates in the Aber in September, the greatest numbers occurred at Site 1 and the least at Site 5, with relatively even numbers at the three intermediate sites (Figure 2).

In December, the three basic distribution patterns were still evident, however there were some notable changes. Most of the freshwater taxa showed extended ranges (e.g. the caddisflies, mayflies and chironomid larvae), and/or shifts in their proportions at downstream sites (e.g. the elmid beetles) (Figure 2). Among the marine-derived taxa, there was an apparent retrenchment to the lowermost sites (e.g. as in the bivalves, decapods and fishes), sometimes accompanied by reduced densities (e.g. gastropods). The distribution of the brackishwater taxa remained the same. However, there were marked changes in the distributions of the nematodes, oligochaetes, mites and copepods. The overall distribution pattern had shifted to one where the greatest numbers occurred at Site 3.

In April, the caddisflies, mayflies and stoneflies still penetrated as far as Site 4, and the elmids and chironomids as far as Site 5 (Figure 2). Oligochaetes, mites and ostracods were more uniformly distributed among all five sites, but the amphipods were concentrated at Sites 3-5. Some of the marine taxa, for example, the bivalves and polychaetes, were found in low numbers as far upstream as Site 2 . The greatest numbers of animals again were found at Site 3.

In July, with the exception of the chironomid larvae, the range of most of the aquatic insects had contracted to Sites 1 and 2, with the bulk of the elmids, simuliids and mayflies occurring at Site 2 (Figure 2). The extended distributions of the oligochaetes, nematodes and copepods reflected the presence of more than a single species, and those of the bivalve and ostracod species were clearly disjunct. Marine-derived taxa were typically found at, and downstream from, Site 3. Highest overall densities were at Sites 1 and 2 .

Whereas the densities of most insect taxa dropped substantially downstream from Site 1 , there were significant numbers present further down the estuary at certain times of the year. For example, the densities of chironomid larvae at Sites 1 and 3 were not significantly different in either April or July (April: $481.0 \pm 106.9$ and $576.7 \pm 49.5$ larvae $900 \mathrm{~cm}^{-2}$; July: $\quad 565 \cdot 7 \pm 128 \cdot 8$ and $507 \cdot 7 \pm 38 \cdot 4$ larvae $900 \mathrm{~cm}^{-2}$; Student's $\mathrm{t}=-0.81$ and 0.43 , respectively; $\mathrm{P}>0.4$ ). Further, in April, at Site 4 (inundated by $81 \%$ of all high tides), a mean of $316 \cdot 3 \pm 41 \cdot 4$ larvae was recorded on only $900 \mathrm{~cm}^{2}$ of estuary bed $\left(3514 \mathrm{~m}^{-2}\right)$. Even at Site 5, inundated by all high tides, there were $67 \cdot 3 \pm(31 \cdot 1)$ larvae $900 \mathrm{~cm}^{-2}$ $\left(747 \mathrm{~m}^{-2}\right)$. Among the larger aquatic insects, caddisfly and elmid beetle larvae together with stonefly nymphs were consistently taken at Site 4, although their densities were lower. Nevertheless, when expressed on a $\mathrm{m}^{-2}$ basis the numbers are unexpectedly high (e.g. a maximum of 48 caddisfly larvae $\mathrm{m}^{-2}$ in December and 70 elmids $\mathrm{m}^{-2}$ in April).

Summarizing the proportional representation of the freshwater, brackishwater and saltwater species in the classical style (sensu Remane \& Schlieper, 1971) (Figure 3), shows a predominance of the first two categories. This confirms the earlier hydrological designation of the Aber Estuary as being of the freshwater-dominated type.

\section{Export dynamics}

Environmental conditions measured during the time the drift samples were taken are summarized in Table 1. Also shown are the total drift densities and biomasses, together with the amounts and types of organic materials entering the estuary from upstream. The lowest drift densities consistently occurred during late autumn and winter, whereas the highest density occurred in July. Peak drift biomass occurred in late spring (April/May), a time when many lotic insects are in their largest immature stages, prior to emergence as terrestrial adults. Peak allochthonous input was during late autumn and consisted primarily of shed riparian leaves. Multiple regression analysis applied to this dataset revealed no statistically significant relationships between either total drift density or total drift biomass and any of the measured environmental variables (overall $r^{2}=0 \cdot 27 ; P>0 \cdot 3$, and $r^{2}=0 \cdot 17 ; P>0 \cdot 5$, respectively). Stepwise regression further revealed no significant single variable correlations.

The total invertebrates brought into the estuary on incoming tides varied between $1 \cdot 8$ and $94.6 \%$ (August and June, respectively) of the numbers brought down by the river (Tables 1 and 2). However, the taxonomic composition from the two sources was quite different. Predominant in the downstream drift were the larvae/ nymphs and pupae of insects, notably midges (Chironomidae), mayflies (Ephemeroptera), stoneflies (Plecoptera) and caddisflies (Trichoptera) (Table 3). Predominant in the ' reverse' drift were copepods, ostracods, amphipods and oligochaetes. Only mites and the brackishwater amphipod Gammarus zaddachi were commonly caught moving in both directions. Amongst the insects, only chironomid larvae moved upstream in appreciable numbers. Peaks in ' reverse' 


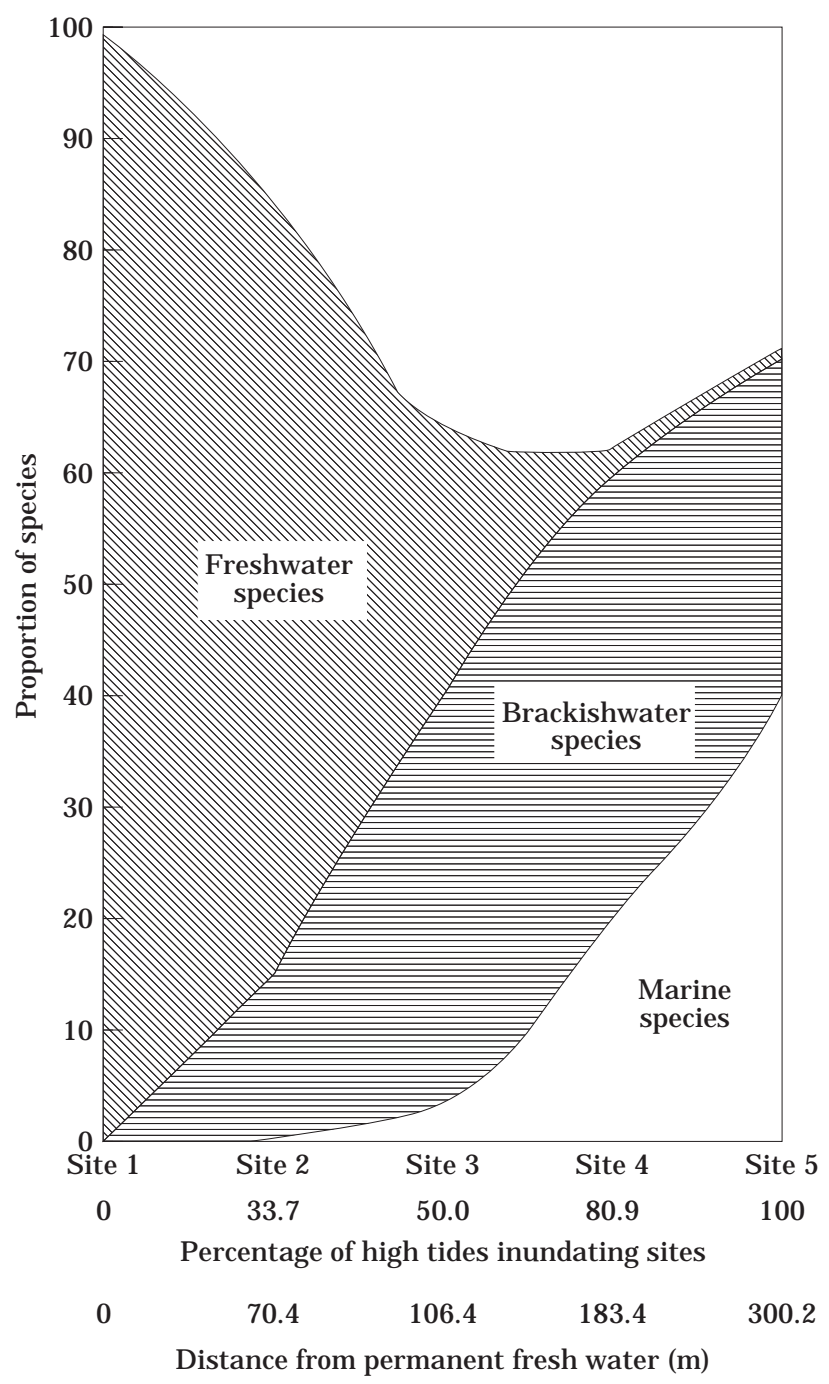

FIGURE 3. Proportional representation of the freshwater, brackishwater and saltwater species in the Aber Estuary expressed both in terms of the linear distance from permanent fresh water (Site 1) and of the percentage of high tides inundating each site with salt water. $\mathbb{Q}$, freshwater species; 自, brackishwater species; $\square$, marine species.

drift biomass occurred from April to June, coinciding with the times of peak ' reverse' drift density. The amount of organic matter entering the estuary from the sea was generally small but peaked when strong onshore winds coincided with high tides (Table 2). Again, multiple and stepwise regression analysis applied to this dataset revealed no relationship between either total ' reverse' drift density or biomass and any of the measured environmental variables (overall $r^{2}=0 \cdot 12 ; P>0 \cdot 6$, and $r^{2}=0 \cdot 35 ; P>0 \cdot 2$, respectively).

Among the larger aquatic insects drifting into the estuary were five species of mayfly, 13 species of stonefly, and 12 species of caddisfly, many of which exhibited different drifting profiles (Table 4). For example, whereas some entered virtually the whole year round (e.g. B aetis rhodani, C hloroperla torrentium, A mphinemura sulcicollis, $\mathrm{H}$ ydropsyche siltalai), others appeared to be more seasonal (e.g. Leuctra hippopus, $L$. inermis, Agapetus delicatulus). Very few of these larger insects moved back upstream into fresh water (Table 4).

Extrapolating the drift data by multiplying them by the cross-sectional area of the estuary (at the net site) and the number of $24 \mathrm{~h}$ periods in specific months, and then totalling the product for each month, provides an estimate of $30.9 \times 10^{6}$ freshwater invertebrates (weighing approximately $62.6 \mathrm{~kg}$, wet weight) entering the estuary per annum. This calculation assumes that drift density was uniform across the estuary channel (which probably produces a slight overestimation) and does not take into account the distances drifted by individuals. Because it represents the numbers passing through a two-dimensional window, and there are many such possible windows along the estuary, an estimate for the total export of freshwater invertebrates into saltwater regions of the estuary is likely to be very much higher. By similar extrapolation, the annual influx of invertebrates brought by incoming tides is estimated to be $1.9 \times 10^{6}$ (weighing $2.5 \mathrm{~kg}$ ), again subject to the same assumptions and errors.

\section{Consumption of invertebrates and fish growth}

Three fish species occur commonly in the Aber Estuary, eel (A nguilla anguilla), flounder (Platichthys flesus) and common goby (Pomatoschistus microps). Eel and flounder were most abundant between sites 2 and 3 , whereas gobies extended from just below Site 2 down to Site 5 . All three species exhibited growth while in the estuary. The smallest elvers $(5 \cdot 9-6 \cdot 8 \mathrm{~cm}$ long) appeared between March and May, and by mid-summer had attained lengths of up to $14 \mathrm{~cm}$ (size class 3; Figure 4). Small (size class 1, 0-1.1 cm) flounders first appeared from March to May, and by June/August many had attained size class $3(2 \cdot 2-$ $3 \cdot 1 \mathrm{~cm}$ ). A few specimens were more than $3 \cdot 2 \mathrm{~cm}$ in length by September/November. The mean wet weight of the flounders when they first appeared in the estuary was $0.005 \mathrm{~g} \pm 0.0002$ ( $\pm 1 \mathrm{SE}$ ), compared with $0 \cdot 54 \mathrm{~g} \pm 0 \cdot 1$ when they left some $30-35$ weeks later. This represents an average weight increase of 108 times. Gobies were most numerous in September-November, however their growth was more difficult to ascertain as fishes from three separate size classes had entered the estuary at this time.

The guts of all but two of the 23 eels dissected were empty (Figure 5). Of the former, one contained a 
402 D. D. Williams \& N. E. Williams

TABLE 2. Environmental data associated with the times at which the upstream samples were taken in the Aber Estuary

\begin{tabular}{|c|c|c|c|c|c|c|}
\hline Date & $\begin{array}{l}\text { Tide } \\
\text { height } \\
\text { (m) }\end{array}$ & $\begin{array}{l}\text { Current/wind } \\
\text { conditions) }\end{array}$ & $\begin{array}{c}\text { Sea } \\
\text { temperature } \\
\left({ }^{\circ} \mathrm{C}\right)\end{array}$ & $\begin{array}{c}\text { Organic } \\
\text { matter }^{a} \\
\text { (g dry wt) }\end{array}$ & $\begin{array}{c}\text { Total } \\
\text { number of } \\
\text { invertebrates }\end{array}$ & $\begin{array}{c}\text { Invertebrate } \\
\text { biomass } \\
\text { (g) }\end{array}$ \\
\hline October & $9 \cdot 73$ & Strong/gale force & $13 \cdot 0$ & $1 \cdot 5$ & 63 & $148 \cdot 6$ \\
\hline November & $9 \cdot 42$ & Strong/onshore & $8 \cdot 0$ & $25 \cdot 5$ & 50 & $577 \cdot 4$ \\
\hline December & $9 \cdot 57$ & Strong/calm & $5 \cdot 0$ & $0 \cdot 08$ & 35 & $438 \cdot 4$ \\
\hline January & $9 \cdot 12$ & Medium-strong/along-shore & $6 \cdot 0$ & $0 \cdot 11$ & 142 & $130 \cdot 1$ \\
\hline February & $9 \cdot 15$ & Medium strong/strong along-shore & $5 \cdot 5$ & $4 \cdot 4$ & 44 & $280 \cdot 6$ \\
\hline March & $8 \cdot 66$ & Weak/calm & $5 \cdot 5$ & $0 \cdot 23$ & 147 & $96 \cdot 5$ \\
\hline May & $9 \cdot 63$ & Medium-strong/along-shore & $11 \cdot 0$ & 0.96 & 304 & $124 \cdot 4$ \\
\hline June & $9 \cdot 45$ & Medium-strong/calm & $13 \cdot 0$ & $3 \cdot 9$ & 510 & $370 \cdot 8$ \\
\hline July & $8 \cdot 41$ & Weak/calm & $14 \cdot 5$ & $0 \cdot 04$ & 31 & $30 \cdot 2$ \\
\hline August & $8 \cdot 84$ & Weak/calm & $15 \cdot 5$ & $0 \cdot 0$ & 63 & $147 \cdot 7$ \\
\hline
\end{tabular}

${ }^{a}$ The small amounts of organic matter collected typically consisted of pieces of fucoid seaweeds, hydroid skeletons, filamentous algae, unidentifiable flotsam, together with terrestrial leaves in the autumn and early winter.

${ }^{b}$ Represents the numbers of animals caught over a 24 -h period-two high tides - converted to a standardized tide height.

single large shrimp (Crangon crangon), the other contained several chironomid larvae. Most of the goby stomachs were at least half full, with $20 \%$ distended. Taxa prominent in the diet varied according to fish size, probably related to respective mouth gape size. Gobies in the $0-1.0 \mathrm{~cm}$ size class primarily ate harpacticoid copepods, oligochaetes and small amphipods (Figure 6), and this was largely true also for individuals in the $1 \cdot 1-2 \cdot 1 \mathrm{~cm}$ size class. The largest gobies, however, fed almost exclusively on larger specimens of Gammarus zaddachi, supplemented by chironomid and other dipteran larvae. Chironomid larvae were extremely important in the diets of all four size classes of flounder examined (Figure 7). Harpacticoid copepods, oligochaetes and small polychaetes were eaten also by flounders in size classes 1 and 2 (up to $2 \cdot 1 \mathrm{~cm}$ long). More than $75 \%$ of the flounder guts examined were at least half full (Figure 5).

Analysis of the diet of the gobies among sites showed them to be quite opportunistic feeders. For example, at upstream Sites 2 and 3 individuals fed mostly on freshwater harpacticoids, mayflies, chironomids, small amphipods and oligochaetes (Figure 8), whereas at Site 4, G. zaddachi was included. At downstream Site 5, polychaetes, other oligochaetes, and marine copepods and ostracods formed the bulk of the diet.

Comparison of the diets of size classes of flounder and goby with similar gape sizes (closest comparison is $2 \cdot 14 \pm 0.06$ and $3.09 \pm 0.09 \mathrm{~mm}$ gape, respectively) gave a food niche overlap index value (Cxy) of $0 \cdot 23$, which is not considered to be biologically significant (Schoener, 1970). Further, determination of Food Niche Breadth (W ; which took into account measures of potential prey availability in the estuary; Petraitis,
1979) showed both gobies and flounder to be specialists (W was close to zero for both species), although, in the case of the gobies, the prey specialized upon varied according to site.

\section{Discussion}

The limited existing faunal data indicate that tidal freshwater habitats have low species diversity, compared with brackish sections of estuaries and the non-tidal sections of rivers (Lopez, 1988), and that the major taxa present are tubificid worms and chironomids, together with molluscs, crustaceans and ' other' insects (Diaz, 1994). The fauna of the Aber Estuary confirms, to some extent, this taxonomic mix although there are important differences. Firstly, taxon richness was even along the entire length of the estuary, in that the 17 major taxonomic groups recorded (Figure 2) were present at all five sampling sites. Further, within the Trichoptera, the most diverse insect group and one which was identified to species, apart from a difference at Sites 1 and 5 (14 and 4 species, respectively), the complement of species was again even (11 species at each of Sites 2, 3 and 4). Second, whereas chironomids and oligochaetes were the numerically dominant taxa, 'other' insects (Trichoptera, Plecoptera, Ephemeroptera, Elmidae and Simuliidae) formed $10 \%$ of the total numbers of organisms collected at the tidal sites (2-5). Numerically, adding the chironomids, aquatic insects made up $32 \%$ of the Aber benthic fauna. The importance of chironomids has been shown also in the James River Estuary, Virginia, where Coelotanypus scapularis, along with the clam Corbicula fluminea and 


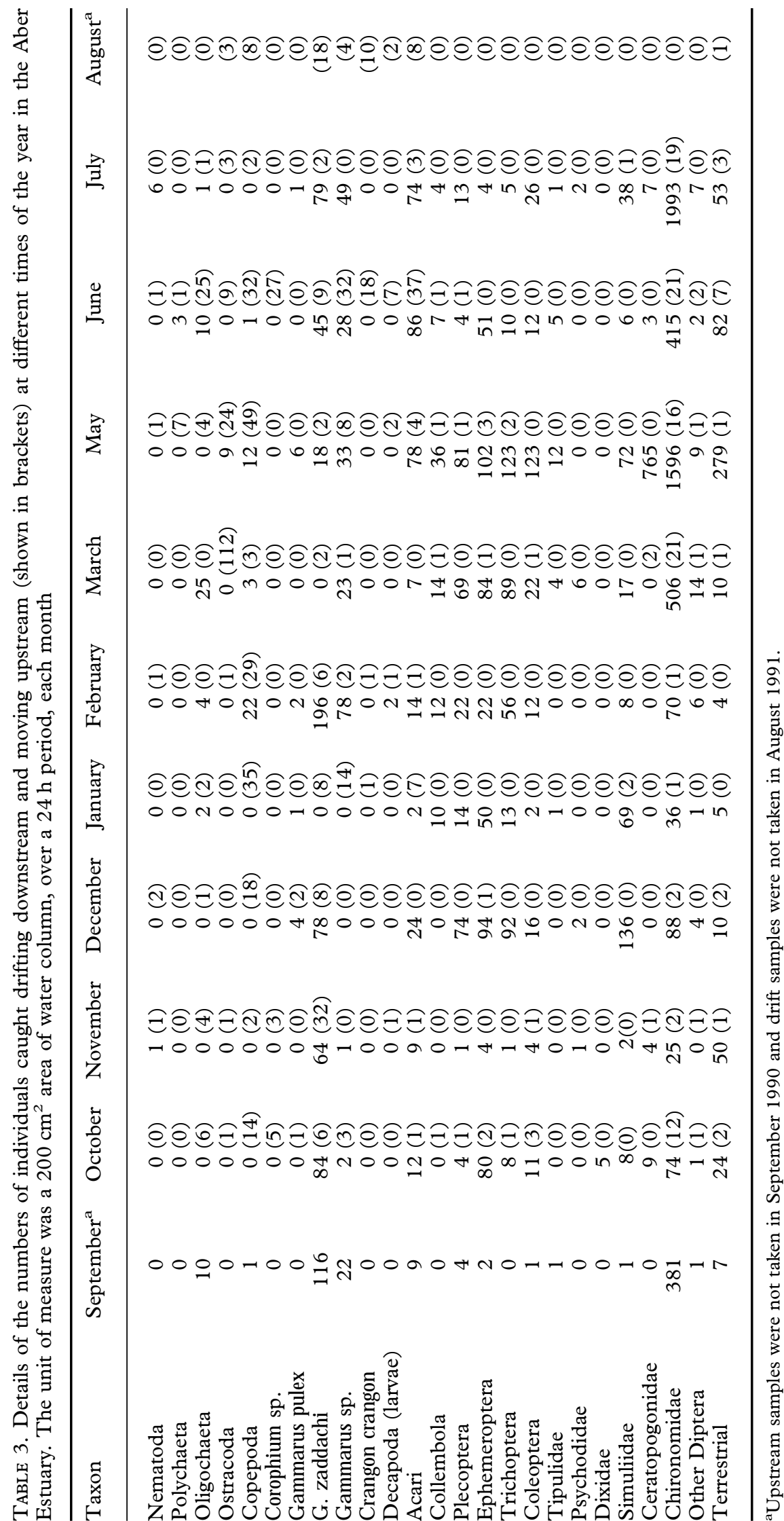


404 D. D. Williams \& N. E. Williams

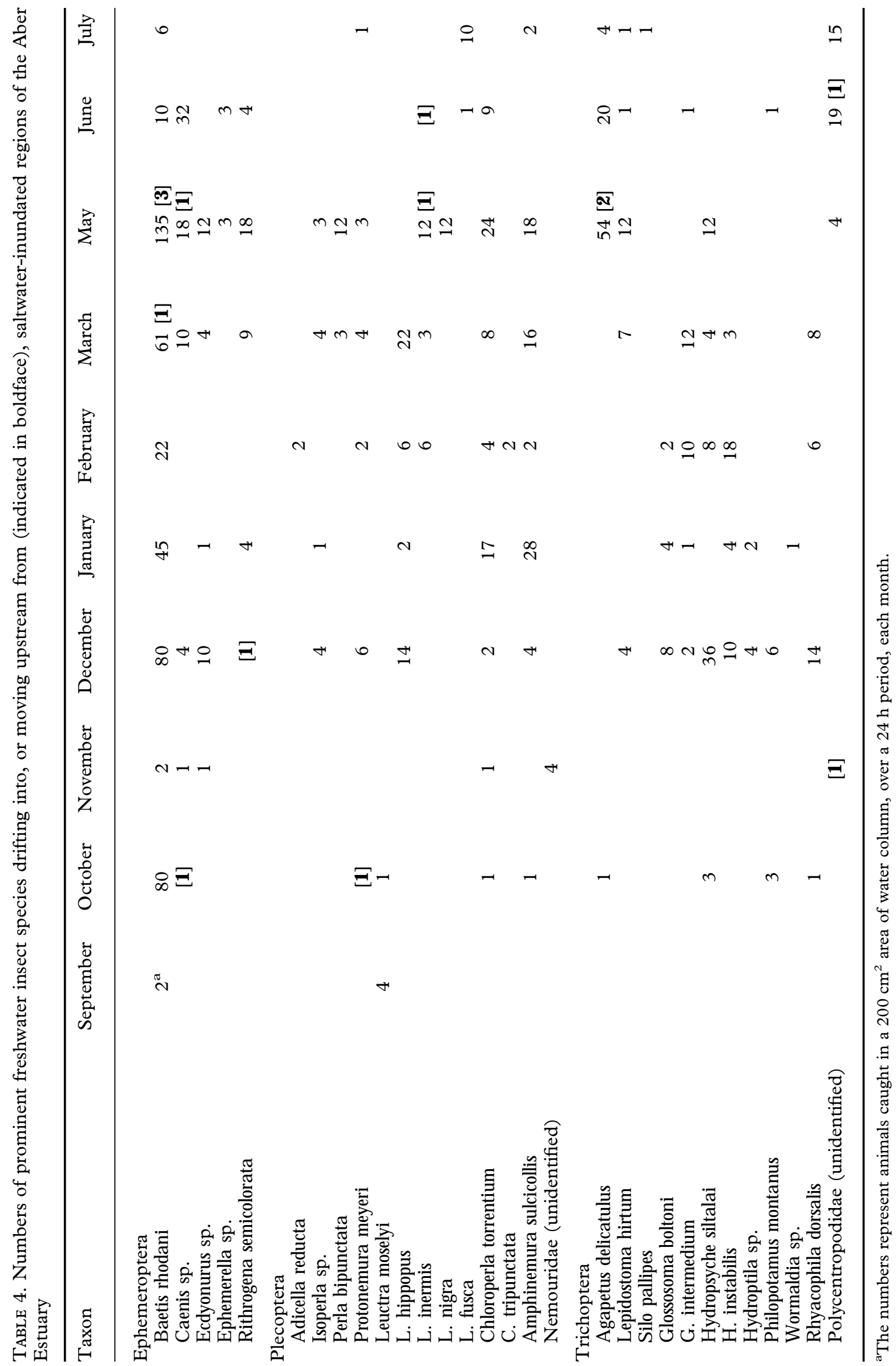



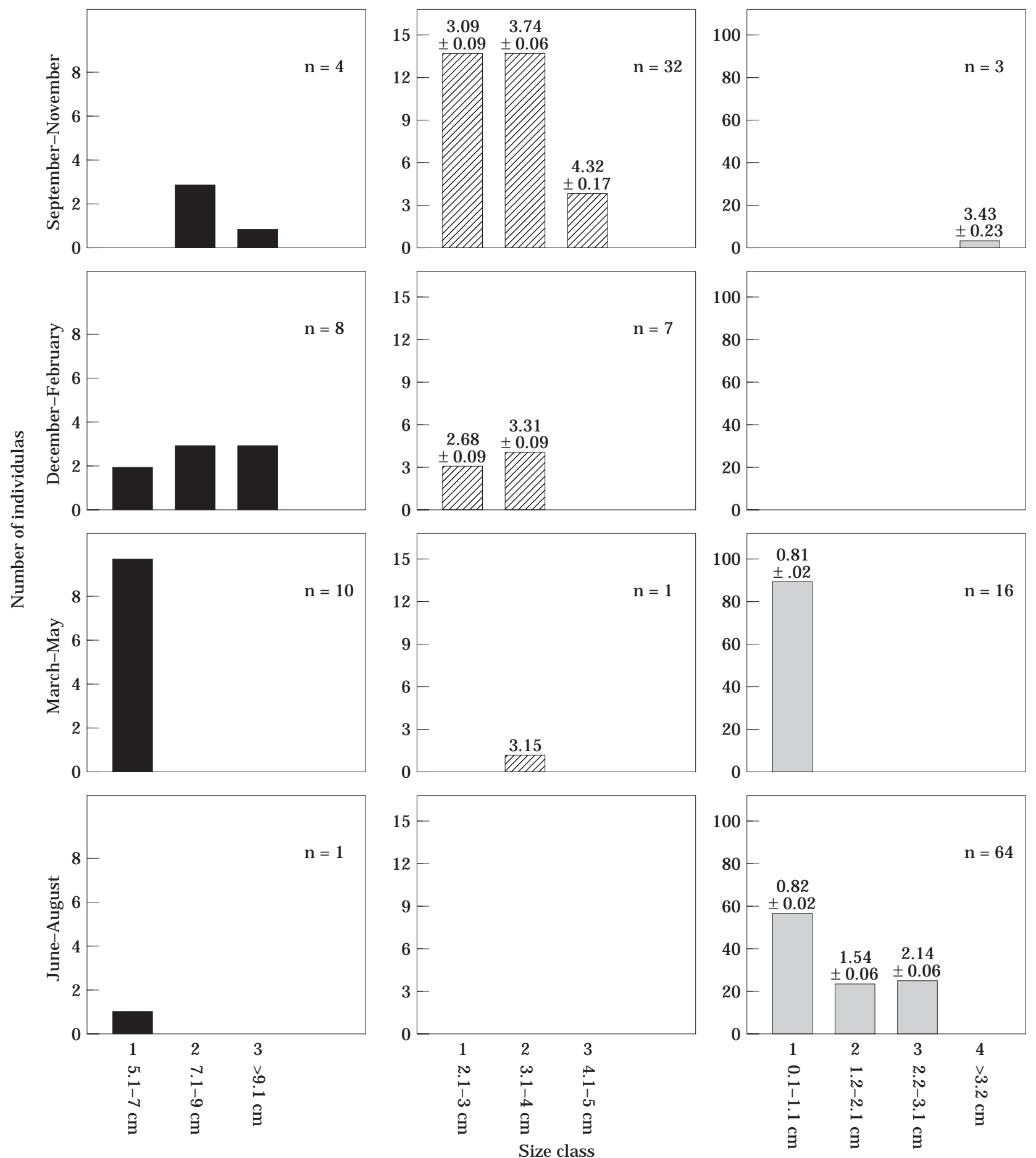

FIGURE 4. Numbers of the three principal species of fish caught in the Aber Estuary throughout the period September 1990 to August 1991. Individuals of each species are assigned to body length size classes. Mean gape size (measured in mm; $\pm 1 \mathrm{SE})$ is also shown for each size class of goby and flounder. $\mathbf{\square}$, eel; 四, goby; 圈, flounder.

tubificid worms (Limnodrilus), dominated the tidal freshwater community (Diaz, 1989).

Clearly, there are differences in the longitudinal zonation patterns among the different taxa living in the Aber. Classic examples of a largely freshwater, upstream distribution (e.g. the mayflies, stoneflies and black flies), a largely marine, downstream distribution (e.g. the decapods, bivalves, gastropods and 
406 D. D. Williams \& N. E. Williams

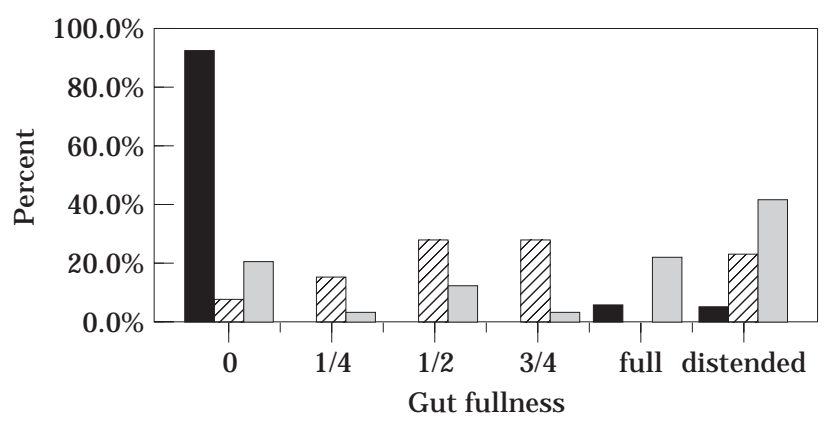

FIGURE 5. Relative fullness of the guts of the three fish species caught in the Aber Estuary. $\square$, eel; 四, goby; $⿴ 囗$ flounder.

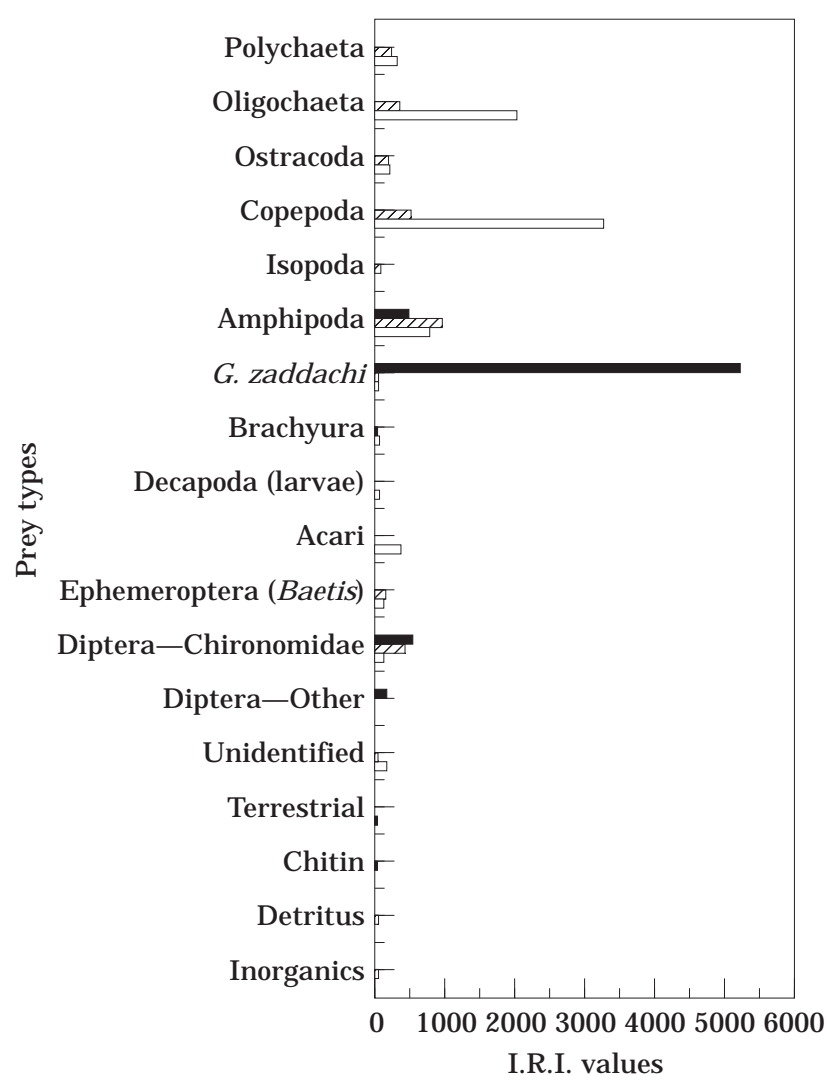

FIGURE 6. Comparison of the diets of gobies in three size classes, using the Index of Relative Importance (I.R.I.) of Pinkas et al. (1971). These classes were based on total body length range rather than on specific cohorts: Class $1=2 \cdot 1-$ $3.0 \mathrm{~cm}$; Class $2=3 \cdot 1-4 \cdot 0 \mathrm{~cm}$; Class $3=4 \cdot 1-5 \mathrm{~cm}$. $\square$, Goby class 3 ; 四, goby class $2 ; \square$, goby class 1 .

polychaetes), and an intermediate, brackishwater, distribution (e.g. the amphipods and isopods) are evident. More interesting, perhaps, are the substantial changes in distribution according to season seen among several taxa. Compared with September, the downstream shift of chironomid larvae in December could be an artifact associated with 10 -fold decrease

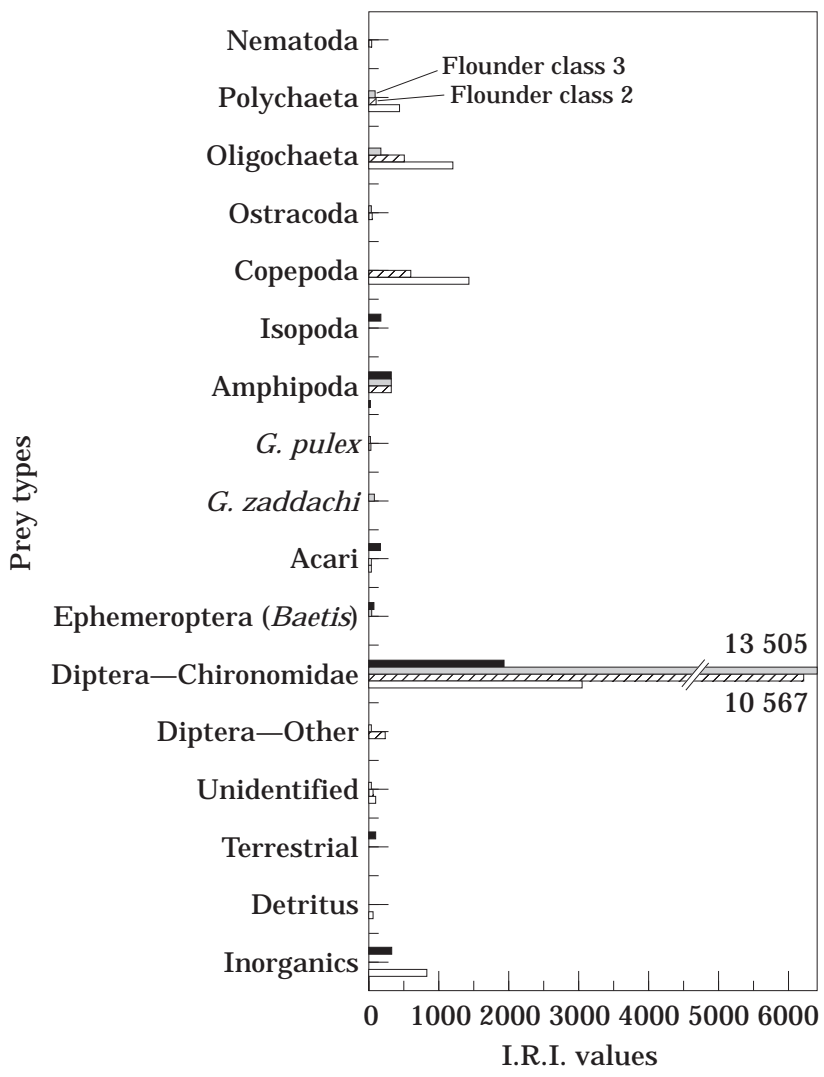

FIGURE 7. Comparison of the diets of flounder in four size classes, using the Index of Relative Importance (I.R.I.) of Pinkas et al. (1971). These classes were based on total body length range rather than on specific cohorts. Class $1=0 \cdot 1-$ $1 \cdot 1 \mathrm{~cm}$; Class $2=1 \cdot 2-2 \cdot 1 \mathrm{~cm}$; Class $3=2 \cdot 2-3 \cdot 1 \mathrm{~cm}$; Class $4=>3 \cdot 2 \mathrm{~cm}$. $\square$, Flounder class 4 ; 睠, flounder class 3; 四, flounder class $2 ; \square$, flounder class 1 .

in overall numbers (Figure 2). However, the even greater extension into saltwater regions, seen in April and July, when numbers were partially restored, suggests that this phenomenon was real. An almost identical pattern was seen in the elmid beetles. The downstream extensions seen in the caddisflies, mayflies and stoneflies were under conditions of stable or increasing population densities. In the case of the black fly Simulium variegatum, huge numbers of larvae were concentrated at Site 2 , in July. The total benthos also showed a downstream shift between September and December, and this was maintained through April and into the summer. Environmental data indicate that the September-December period in the Aber was one of decreasing riverwater temperature (monthly range from $10 \cdot 0-18 \cdot 0{ }^{\circ} \mathrm{C}$ down to $5 \cdot 5-11.0{ }^{\circ} \mathrm{C}$ ) and of increasing discharge (mean monthly discharge: September $=0.32$, October $=0.68$, November $=0.74$, December $=1.5 \mathrm{~m}^{-3} \mathrm{~s}^{-1}$ ). However, water temperature had increased, and discharge had decreased, prior 


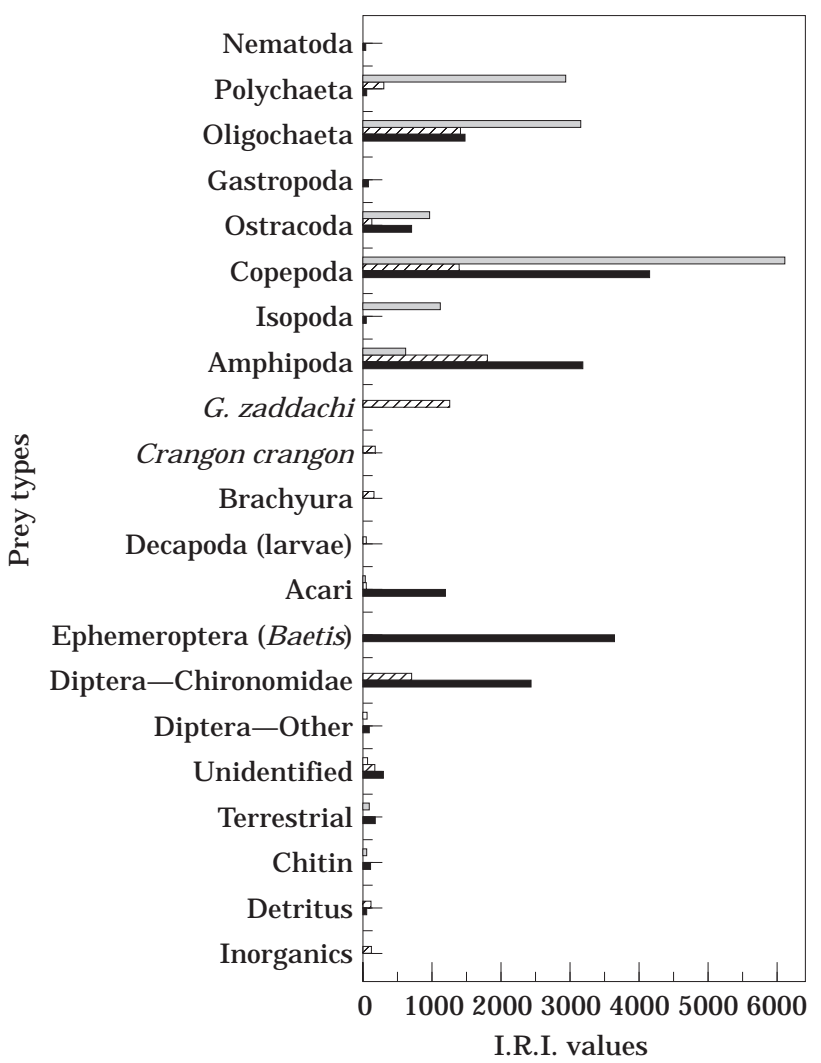

Figure 8. Comparison of the diets of gobies among sites along the Aber Estuary (using the Index of Relative Importance (I.R.I.) of Pinkas et al., 1971). $\square$, Goby site 5; 罝, goby site 4 ; 圈, goby sites $2-3$.

to April and July. Possibly, increased river discharge in the autumn and early winter promoted the observed downstream extensions which were thereafter maintained during the spring and early summer. Subsequent emergence of the adults resulted in decreased densities of immature stages in the benthos and restoration of the upstream distributions seen in September. The chain of events just described attempts to explain the observed distributions through a passive mechanism. Another passive mechanism might be related to seasonal differences in inundation by salt water, due to shifts in tidal amplitude. However, during the September-December downstream faunal shift, high tides were among the highest recorded for the year (e.g. $60 \%$ inundation of Site 3 by all high tides in October and November). Moreover, this distributional shift was maintained in April, the time of maximum saltwater intrusion into the estuary (65\% inundation at Site 3). Saltwater intrusion was least in June/July, by which time the ranges of aquatic insects had contracted to sites 1 and 2. It seems unlikely, therefore, that seasonal variation in saltwater intrusion influenced the observed distributions of the freshwater taxa. However, the upstream extension of marine bivalves and polychaetes (to Site 2) did coincide with the highest recorded saltwater intrusion, in April; juvenile polychaetes are known to be adversely affected by excessive freshwater runoff (Schiedek \& Schöttler, 1991). A competing hypothesis is that the distributions of the freshwater taxa are the result of active migrations made in order to take advantage of more favourable downstream conditions, perhaps in the form of increased food supply or reduced competition. There is little doubt that the stable and large particle size nature of much of the Aber bed substratum facilitates the persistence of lotic invertebrates at downstream sites (Williams \& Feltmate, 1992; McLusky, 1993).

Regardless of whether an active, passive or combined mechanism applies, it is clear that, in the Aber Estuary, large numbers of a wide variety of lotic invertebrate species move across the freshwatersaltwater interface. The qualitative and quantitative nature of this drift varies considerably with time of year although the environmental factors promoting or controlling it are unknown. This is in contrast to other drift studies, even those done on adjacent rivers where, in non-tidal sections, the numbers of animals drifting is related to current speed, water depth and water temperature (Williams \& Williams, 1993; see also reviews by Waters, 1972, and Brittain \& Eikeland, 1988). Among the invertebrates drifting down the Aber were considerable numbers of nymphs and larvae of lotic insects, many of which appeared not simply to die upon passing into tidal sections but resumed a benthic existence by virtue of varying degrees of salt tolerance. Drift therefore provides a mechanism by which the seasonal extensions of many of these species into the lower estuary are facilitated (see also Elliott \& Corlett, 1972).

As perhaps might be expected, neither the numbers nor the taxonomic composition of the ' reverse' drift were similar to those recorded in non-tidal waters. Typically, species found moving upstream are the same as those found in the drift, and some studies have shown a positive correlation between the numbers moving downstream and upstream (Williams \& Williams, 1993). Non-tidal waters, of course, do not exhibit a reversal of flow at incoming tides, the latter probable affecting the composition of the upstreammoving component. Palmer (1984), for example, has shown that the meiofauna of the North Inlet Estuary, South Carolina crawled to the bed surface only during periods of slack tide, and appearance in the drift was attributed to passive dislodgement of individuals inadvertently exposed to currents. Others (e.g. Beukema \& de Vlas, 1989) have demonstrated a 
definite behavioural component in drift entry (as has long been known in fresh waters; e.g. Hildrew \& Townsend, 1980; Williams \& Moore, 1989). However, not all taxa (e.g. nematodes) participate in such active migrations (Armonies, 1994). Composition of the reverse drift assemblage in the Aber reflects its lower estuarine/marine origin, and the presence of Gammarus zaddachi in both types of drift traps underlines its high level of activity within the brackish, middle reach of the estuary. It is well known that sediment-dwelling marine crustaceans, particularly amphipods and isopods, have swimming patterns strongly linked to environmental cues (e.g. Jones \& Naylor, 1970; Grant, 1980; Naylor, 1985; Schlacher \& Wooldridge, 1994), especially water movement and often in combination with other cues such as photoperiod. In the Aber, with the exception of the more numerous chironomids, lack of most of the larger aquatic insects in the reverse drift might be explained by their reduced downstream densities or by the weak, in comparison with the freshwater flow, saltwater currents.

The total annual drift recorded for the Aber (30 872107 individuals) compares favourably with estimates made in other larger, British rivers, for example 374125-10901820 in the River Yarty, Devon, and 16811900 to 147225670 in the River Leven, Cumbria (Bailey, 1966; Elliott \& Corlett, 1972). We could find no records of comparable measurements of reverse drift elsewhere.

The fact that such large numbers of lotic invertebrates are being carried into the Aber Estuary and are becoming established in tidal sections begs the question of whether they benefit, significantly, estuarine consumers. For the two major fish species in the Aber the answer is clearly yes. In the case of the flounders, they entered the estuary as very small, post-pelagic larvae (mean weight $=0.005 \mathrm{~g}$, mean length $=0.95 \mathrm{~cm}$ ) in the spring and fed primarily on chironomid larvae until they migrated out to sea in the autumn. By then, individual biomass had increased more than 100 -fold (mean weight $=0.54 \mathrm{~g}$, mean length $=4.1 \mathrm{~cm}$ ). Adult flounders were never encountered in the Aber. Larval, pupal and adult chironomids also have been shown to be important in the diets of juvenile salmonids in estuaries along the west coast of North America (Wolf et al., 1983; Levings et al., 1991). Interestingly, in July, chironomids were still the dominant prey type at Site 2, despite the presence of large populations of black fly (Simuliidae) larvae and B aetis (Ephemeroptera) nymphs, both of which occurred uncommonly in the guts. Simuliids tend to attach themselves to the upper surfaces of substratum particles, whereas chironomids typically live between and beneath stones and gravel, where they are more accessible to the strongly benthic feeding behaviour of flounder. B aetis nymphs are extremely active and frequently enter the water column when approached by a predator (Williams, 1987). The absence of caddisfly larvae in the diets may be due to large size and the protection afforded by their cases in some species, and, in the abundant glossosomatids, both a strong case and an upper-substratum-surface existence.

Flounder diets have been examined in several other estuarine locations and considerable variability noted. For example, in the Tamar Estuary, Devon, the most common prey were the crustaceans Crangon vulgaris, $\mathrm{N}$ eomysis vulgaris and Schistomysis ornata (Hartley, 1940); in estuaries along the Danish coast, flounder around $1.0 \mathrm{~cm}$ in length fed primarily on harpacticoid copepods together with small annelids (Bregnballe, 1961); in the Elbe, Germany, guts contained tubificid oligochaetes and freshwater clams (Sphaerium) (Stadel, 1936); and in the River Tweed, Scotland, approximately $88 \%$ of the diet consisted of chironomid larvae (Radforth, 1940). However, individuals in the latter population of flounder averaged $17.6 \mathrm{~cm}$ in length. In the Fraser River estuary, British Columbia, Canada, the main prey of the Starry flounder (Platichthys stellatus) consists of oligochaetes, small crustaceans and insects (Northcote et al., 1979).

Freshwater invertebrates, particularly chironomid larvae, were eaten on a regular basis also by the larger gobies, especially at upstream Sites 2 and 3. B aetis mayfly nymphs, small amphipods ( $G$ ammarus pulex), freshwater mites and copepods were consumed at these two sites as well. However, it was G. zaddachi that was the most important prey. As in this study, populations of the common goby, elsewhere, have demonstrated feeding differences from one part of an estuary to another. In freshwater sections of the Gwendraeth Estuary, Wales, for example, chironomid larvae, oligochaetes and harpacticoids were the major dietary items and this put the gobies into direct competition with minnows (Phoxinus). In pools in the surrounding salt marsh, the predominant prey consisted of harpacticoids and halacarid mites. Further seaward, guts contained mostly the broken off limbs of barnacles, together with various small crustaceans, mites and polychaetes (Green, 1968).

In the Aber, food resource partitioning appears to occur between these two fish species. The evidence for this includes: (1) differences in the predominant taxa eaten, which may be related to (2) a difference in the range of mouth gapes of the size classes present; (3) a difference in peak residency times in the estuary (gobies from September to February; flounder from March to August); and (4) some difference in their 
spatial distribution in the estuary (flounder at Sites 2 and 3; gobies at Sites 2-5, but more abundantly at Sites 3-5. Any overlap with eels in the Aber could not be assessed due to the large proportion of empty guts recorded $(91 \%)$ in this species.

In comparison with the research effort devoted to assessing the nature of drift in rivers and streams, that directed at tidally-influenced lotic waters is very sparse. This is despite the fact that existing studies have shown important consequences of lotic discharge. It has been shown, for example, that spring discharge from the St. Lawrence Estuary may promote the aggregation of planktonic food organisms as well as larval fishes. Indeed, it is speculated that the arrival of Atlantic mackerel in this region, to spawn, is timed to precede this annual freshet by just the time needed for their eggs to hatch and the larval egg yolks to be consumed (Coté et al., 1986). Further, freshwater inflow to the San Antonio Bay, Texas has been shown, through input of organic matter and nutrients, to stimulate microbial production, to increase the feeding rates of small, brackishwater invertebrates, and to influence meiobenthic community structure (Montagna \& Yoon, 1991). Deegan et al. (1994) have hypothesized that differences in organic matter inputs among estuaries may influence the diversity and productivity of resident fish populations. The importance of estuaries in retaining allochthonous detritus and the latter's importance at the base of the estuarine food web leading to support of the immature stages of important fish species is being increasingly acknowledged (e.g. Healey, 1982; Thorpe, 1994). What needs to be appreciated more, however, is the direct and immediate input to juvenile fish diets from upstream-derived invertebrates.

\section{Acknowledgements}

For access to the Aber Estuary and foreshore we thank the following custodians and property owners: Lady Janet Douglas Pennant, Penrhyn Castle Estate; College Farm, University of Wales, Bangor; the Countryside Council for Wales; the Wildfowler's Club; and the north-western and North Wales Sea Fisheries Committee. We are also grateful to $\mathrm{Dr}$ Maurice Lock and the School of Biological Sciences, University of Wales, Bangor for providing excellent research facilities. Our biggest debt of gratitude, however, goes to Marilyn Smith for her unsurpassed technical skills.

\section{References}

Armonies, W. 1994 Drifting meio- and macrobenthic invertebrates on tidal flats in Könighafen: a review. H elgoländer M eeresunters 48, 299-320.
Bailey, R. G. 1966 Observations on the nature and importance of organic drift in a Devon river. H ydrobiologia 27, 353-367.

Bassett, D. A. 1967 A Source-book of Geological, Geomorphological and Soil M aps for Wales and the Welsh Borders (1800-1966). Amgueddfa Genedlaethol Cymru, Cardiff, $239 \mathrm{pp}$.

Beukema, J. J. \& de Vlas, J. 1989 Tidal-current transport of thread-drifting postlarval juveniles of the bivalve $\mathrm{M}$ acoma balthica from the Wadden Sea to the North Sea. M arine Ecology Progress Series 52, 193-200.

Boesch, D. F., Wass, M. L. \& Virnstein, R. W. 1976 The dynamics of estuarine benthic communities. In Estuarine Processes, V ol. I. U ses, Stress and Adaptations to the Estuary (Wiley, M., ed.). Academic Press, New York, pp. 177-196.

Bregnballe, F. 1961 Plaice and flounder as consumers of the microscopic bottom fauna. $M$ eddelelser $D$ anmark $F$ isk $H$ avundersogelser K obenhaven 3, 133-182.

Brittain, J. E. \& Eikeland, T. J. 1988 Invertebrate drift-a review. H ydrobologia 166, 77-93.

Brown, E. H. 1960 The Relief and D rainage of Wales, a Study in $\mathrm{G}$ eomorphological D evelopment. University of Wales Press, Cardiff, $186 \mathrm{pp}$.

Coté, B., El-Sabh, M. \& de la Durantaye, R. 1986 Biological and physical characteristics of a frontal region associated with the arrival of spring freshwater discharge in the southwestern Gulf of the St. Lawrence. In The R ole of F reshwater O utflow in Coastal $M$ arine E cosystems (Skreslet, S., ed.). NATO ASI Series, Series G, Ecological Sciences, No. 7. Springer, Berlin, pp. 261-269.

Cunha, M. R. \& Moreira, M. H. 1995 Macrobenthos of Potamoge ton and M yriophyllum beds in the upper reaches of Canal de Mira (Ria de Aveiro, NW Portugal): community structure and environmental factors. N etherlands J ournal of A quatic Ecology $\mathbf{2 9}$, 377-390.

Day, J. W., Halls, C. A. S., Kemp, W. M. \& Yanez-Arancibia, A. (eds) 1989 Estuarine Ecology. John Wiley \& Sons, New York, $558 \mathrm{pp}$.

Deegan, L. A., Finn, J. T., Hopkinson, C. S., Giblin, A. E., Peterson, B. J., Fry, B. \& Hobbie, J. E. 1994 Flow model analysis of the effects of organic matter-nutrient interactions on estuarine trophic dynamics. In Changes in F luxes in Estuaries: Implications from Science to M anagement (Dyer, K. R. \& Orth, R. J., eds). Olsen \& Olsen, Fredensberg, pp. 273-281.

Delbeek, J. C. \& Williams, D. D. 1987 Food resource partitioning between sympatric populations of brackishwater sticklebacks. J ournal of A nimal E cology 56, 949-967.

Diaz, R. J. 1989 Pollution and tidal benthic communities of the James River Estuary, Virginia. H ydrobiologia 180, 195-211.

Diaz, R. J. 1994 Response of tidal freshwater macrobenthos to sediment disturbance. H ydrobiologia 278, 201-212.

Elliott, J. M. \& Corlett, J. 1972 The ecology of Morecambe Bay IV. Invertebrate drift into and from the River Leven. J ournal of A pplied E cology 9, 195-205.

Grant, J. 1980 A flume study of drift in marine infaunal amphipods (Haustoriidae). M arine B iology 56, 79-84.

Green, J. 1968 The Biology of Estuarine Animals. Sidgwick \& Jackson, London, $401 \mathrm{pp}$.

Hartley, P. H. T. 1940 The Saltash tuck-net fishery and the ecology of some estuarine fishes. J ournal of the $M$ arine B iological A ssociation of the U nited $\mathrm{K}$ ingdom $\mathbf{2 4}, 1-68$.

Healey, M. C. 1982 Juvenile Pacific salmon in estuaries: the life support system. In E stuarine Comparisons (Kennedy, V. S., ed.). Academic Press, New York, pp. 315-341.

Hildrew, A. G. \& Townsend, C. R. 1980 Aggregation, interference and foraging by larvae of Plectrocnemia conspersa (Trichoptera: Polycentropodidae). A nimal B ehaviour 28, 553-560.

Jones, D. A. \& Naylor, E. 1970 The swimming rhythm of the sand beach isopod Eurydice pulchra. J ournal of Experimental $M$ arine Biology and Ecology 4, 188-199.

Laffoley, D. \& Hiscock, K. 1993 The classification of benthic estuarine communities for nature conservation assessments in Great Britain. N etherlands J ournal of A quatic E cology 27, 181-187. 
Levings, C. D., Conlin, K. \& Raymond, B. 1991 Intertidal habitats used by juvenile chinook salmon (O ncorhynchus tshawytscha) rearing in the North Arm of the Fraser River estuary. M arine Pollution B ulletin 22, 20-26.

Lopez, G. R. 1988 Comparative ecology of the macrofauna of freshwater and marine muds. Limnology and 0 ceanography 33, 946-962.

McLusky, D. S. 1993 Marine and estuarine gradients-an overview. N etherlands J ournal of A quatic E cology 27, 489-493.

McLusky, D. S., Hull, S. C. \& Elliott, M. 1993 Variations in the intertidal and subtidal macrofauna and sediments along a salinity gradient in the upper Forth Estuary. N etherlands J ournal of A quatic E cology 27, 101-109.

Montagna, P. A. \& Yoon, W. B. 1991 The effect of freshwater inflow on meoifaunal consumption of sediment bacteria and microphytobenthos in San Antonio Bay, Texas, U.S.A. Estuarine, Coastal and Shelf Science 33, 529-547.

Naylor, E. 1985 Tidally rhythmic behaviour of marine animals. Symposium of the Society for Experimental Biology 39, 63-93.

Northcote, T. G., Johnson, N. T. \& Tsumura, K. 1979 Feeding relationships and food web structures of lower Fraser River fishes. University of B ritish Columbia R esearch Centre T echnical R eport $\mathrm{N} 0$. 16, $73 \mathrm{pp}$.

Odum, W. E., Smith, T. J., Hoover, J. K. \& McIvor, C. C. 1984 The ecology of tidal freshwater marshes of the United States east coast: a community profile. U nited States Fish \& W ildlife Service D ocument FWS/OBS-83/17, 1-177.

Palmer, M. A. 1984 Invertebrate drift: behavioural experiments with intertidal meiobenthos. M arine Behavioural Physiology 10, 235-253.

Perkins, E. J. 1974 The Biology of Estuaries and Coastal W aters. Academic Press, London, 678 pp.

Petraitis, P. S. 1979 Likelihood measures of niche breadth and overlap. E cology 60, 703-710.

Pinkas, L., Oliphant, M. S. \& Iverson, I. L. K. 1971 Food habits of albacore, bluefin tuna and bonito in California waters. California $\mathrm{F}$ ish and Fisheries B ulletin 152, 1-105.

Radforth, I. 1940 The food of the grayling (Thymallus thymallus), flounder (Platichthys flesus), roach (Rutilus rutilus) and gudgeon (G obio fluviatilis) with special reference to the Tweed watershed. J ournal of A nimal Ecology 9, 302-318.
Remane, A. \& Schlieper, C. 1971 Die Biologie des Brackwassers. Second Edition. Die B innengewasser 25, 1-372.

Schiedek, D. \& Schöttler, U. 1991 The influence of freshwater runoff on the population density of juvenile A renicola marina L. (Polychaeta). In Estuaries and Coasts: Spatial and T emporal Intercomparisons (Elliott, M. \& Ducrotoy, J. P., eds). Olsen \& Olsen, Fredensberg, pp. 195-200.

Schlacher, T. A. \& Wooldridge, T. H. 1994 Tidal influence on the distribution and behaviour of the estuarine opossum shrimp $\mathrm{G}$ astrosaccus brevifissura. In Changes in Fluxes in Estuaries: Implications from Science to M anagement (Dyer, K. R. \& Orth, R. J., eds). Olsen \& Olsen, Fredensberg, pp. 307-312.

Schoener, T. W. 1970 Non-synchronous spatial overlap of lizards in patchy habitats. E cology 51, 408-418.

Schuchardt, B., Haesloop, U. \& Schirmer, M. 1993 The tidal freshwater reach of the Weser Estuary: riverine or estuarine? $\mathrm{N}$ etherlands J ournal of A quatic E cology 27, 215-226.

Stadel, O. 1936 Nahrungsuntersuchungen an Elbfischen. Zeitschrift für $\mathrm{F}$ ischerei und deren $\mathrm{H}$ ilfswissenschaften 34, 45-61.

Surber, E. W. 1937 Rainbow trout and bottom fauna production in one mile of stream. Transactions of the A merican F isheries Society 66, 193-202.

Thorpe, J. E. 1994 Salmonid fishes and the estuarine environment. Estuaries 17, 76-93.

Waters, T. F. 1972 The drift of stream insects. Annual Review of Entomology 17, 253-272.

Williams, D. D. 1980 Invertebrate drift lost to the sea during low flow conditions in a small coastal stream in Western Canada. $\mathrm{H}$ ydrobiologia $\mathbf{7 5}, 251-254$.

Williams, D. D. 1987 A laboratory study of predator-prey interactions of stoneflies and mayflies. F reshwater B iology 17, 471-490.

Williams, D. D. \& Feltmate, B. W. 1992 A quatic Insects. C.A.B. International, Wallingford, Oxford, $358 \mathrm{pp}$.

Williams, D. D. \& Moore, K. A. 1989 Environmental complexity and the drifting behaviour of a running water amphipod. Canadian J ournal of F isheries and A quatic Sciences 46, 1520-1530.

Williams, D. D. \& Williams, N. E. 1993 The upstream/downstream movement paradox of lotic invertebrates: quantitative evidence from a Welsh mountain stream. Freshwater B iology 30, 199-218.

Wolf, E. G., Morson, B. \& Fucik, K. W. 1983 Preliminary studies of food habits of juvenile fish, China Poot Marsh and Potter Marsh, Alaska, 1978. Estuaries 6, 102-114. 